\title{
Article \\ Planktonic Biota Constituents Responses to Global Sea-Level Changes Recorded in the Uppermost Albian to Middle Cenomanian Deep-Water Facies of the Outer Carpathians
}

\author{
Zbigniew Górny ${ }^{1}$, Marta Bąk ${ }^{1, * \mathbb{D}}$, Krzysztof Bąk ${ }^{2} \mathbb{D}$ and Piotr Strzeboński ${ }^{1}$ (D) \\ 1 Faculty of Geology, Geophysics and Environmental Protection, AGH University of Science and Technology, \\ Mickiewicza 30, 30-059 Krakow, Poland; gorny.zbigniew.agh@gmail.com (Z.G.); strzebo@agh.edu.pl (P.S.) \\ 2 Faculty of Biology and Geography, Department of Geology, Pedagogical University of Cracow, \\ Podchorążych 2, 30-084 Krakow, Poland; krzysztof.bak@up.krakow.pl \\ * Correspondence: martabak@agh.edu.pl
}

check for updates

Citation: Górny, Z.; Bạk, M.; Bąk, K.; Strzeboński, P. Planktonic Biota Constituents Responses to Global Sea-Level Changes Recorded in the Uppermost Albian to Middle Cenomanian Deep-Water Facies of the Outer Carpathians. Minerals 2022, 12, 152. https://doi.org/10.3390/ $\min 12020152$

Academic Editor: Aleksey Sadekov

Received: 8 November 2021

Accepted: 25 January 2022

Published: 26 January 2022

Publisher's Note: MDPI stays neutral with regard to jurisdictional claims in published maps and institutional affiliations.

Copyright: (c) 2022 by the authors. Licensee MDPI, Basel, Switzerland. This article is an open access article distributed under the terms and conditions of the Creative Commons Attribution (CC BY) license (https:// creativecommons.org/licenses/by/ $4.0 /)$.

\begin{abstract}
Interpretations of sea-level changes over geological time are mainly based on analyses of sediments deposited within stable platforms. One of the criteria for recognizing these changes is the composition of skeleton-bearing protists living in environments close to the shoreline and on the continental shelf. It can be assumed that the source of information about sea-level changes may also be found in assemblages of microfossils redeposited from the shelf to the marginal ocean basin. With such an assumption, this article presents an interpretation of changes in marine plankton communities (radiolarians and planktonic foraminifera), which during late Albian-middle Cenomanian were redeposited with carbonate mud by gravity currents from the peri-Tethyan shelf to the northern, marginal Silesian Basin of the Western Tethys. Planktonic biota identified in sediments deposited by gravity flows and those found in hemipelagic shales separating them, indicate that their composition may be correlated with eustatic changes in the sea level from the late Albian (KAl8) to middle Cenomanian (KCe3).
\end{abstract}

Keywords: sea-level change; mixed siliciclastic and calcareous turbidite; OAE1d; Mid-Cenomanian Event; Silesian Nappe; peri-Tethyan shelf; spiculite

\section{Introduction}

The late Albian through middle Cenomanian period is characterized by a stepwise sea level rise that led to one of the highest sea levels recorded in the history of the Earth [1]. These long-term processes caused the development of wide epicontinental seas in the Northern hemisphere with variable pelagic carbonate lithofacies and biogenic siliceous sponge facies [2]. The short-term sea-level fluctuations are estimated at approximately 25-75 m (KAl8-Kce3; [1]), and resulted in stepwise environmental changes on shelves, both in the water column and on the seabed. They caused biotopes migration, and altered biogenic production, therefore shifting each facies areas coverage.

To interpret sea-level changes in the geologic past, planktonic foraminifera and polycystine radiolarians can be applied as palaeoenvironment indicators. Even as redeposited micro-constituents, these genera still display an obvious relationship to the specific water temperature, and thus indicate zones in the water column where they inhabited. Differences in the availability of food, nutrients supply and oxygenation may be additional factors influencing the water depth preferred by a group of organisms (e.g., [3-5]).

The usefulness of planktonic foraminifera in interpreting sea-level changes is based on a depth zonation model successfully applied to modern and fossil morphotypes (e.g., [6-8]), and it is widely used for palaeoenvironmental analyses applied to regions with carbonate sedimentation, in either the deep ocean or in epicontinental seas (e.g., [9-11]). Such interpretations are limited by the abundance of foraminiferal shells which dramatically 
decreases (with a decrease in taxonomic diversity) in deep sea basins, i.e., below the calcareous foraminiferal lysocline but also in marginal basins affected by gravitation flows where biogenic material is transported from surrounding shelves (e.g., [12,13]). In these deposits, agglutinated foraminifera dominate over other microfossils, and planktonic assemblages are rare or they are absent. In such cases, the use of planktonic foraminifera for interpretation of sea-level changes might be based only on redeposited foraminiferal tests.

Polycystine radiolarians with their abundant opaline skeletons in the fossil record can trace specific hydrographic environments also associated with long- and short-periodic changes in the sea level [14]. This group can inhabit a wide range of water depths in the epipelagic and mesopelagic zones [15]. Individual radiolarian species are also restricted to geographical and bathymetrical provinces (e.g., [16]). A majority of modern polycystine radiolarians inhabit nutrient-rich surface waters, and are known to be particularly abundant in sediments that accumulated under eutrophic waters, such as those characteristics of upwelling areas, while others being symbiont-bearing live in oligotrophic environments [17].

These environmental and sedimentary processes were particularly important for the distribution of biotic constituents in epicontinental seas along the West European Platform as well as on the European peri-Tethyan shelves during the late Albian to Cenomanian. Such processes also played an important role in mass-deposition into the deep Outer Carpathian basins, spreading out along the southern margin of the European Platform, where biogenic particles were transported by turbidity currents from sediments under shallower water depths and mixed to lithologically different types of deep-water deposits (e.g., [18]). The sediments of these shelves are covered by the Carpathian nappes, which consist of strata, $\sim 2-8 \mathrm{~km}$ thick (e.g., $[19,20])$, hence, are not available for direct research. Therefore, our study focusses on redeposited biogenic particles derived from shallow material, transported into the deep Carpathians basins (Figure 1). An excellent example of such type of sediments are the upper Albian through middle Cenomanian sequence of the Silesian Nappe, deposited below the CCD in the (marginal) Silesian Basin, (the Carpathian domain of the Western Tethys [21,22]), which derived from the peri-Tethyan shelf [18]. We have used polycystine radiolaria and planktonic foraminifera because they are very common in these deposits and are also abundant in other neritic environments of the Southern Tethyan area (e.g., [23-26]). 

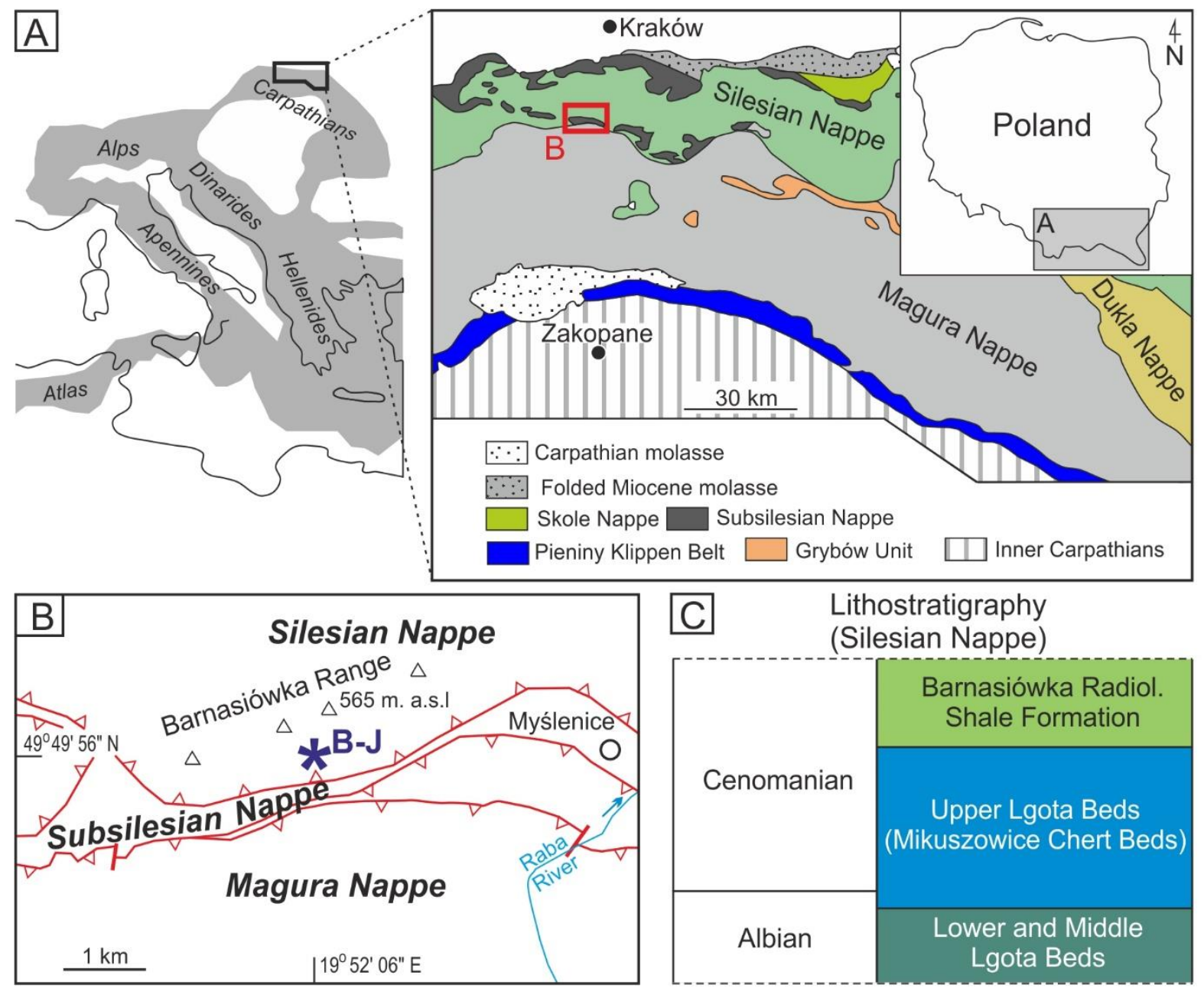

Figure 1. (A) A simplified geological map of the Alpine orogeny and its foreland, with marked area of the Western Central Carpathians [27] in its Polish part. (B) Detailed geological map of the studied area (a part of the Outer Carpathians after [28]) with location of the study area (Barnasiówka-Jasienica quarry; B-J). (C) Albian-Cenomanian lithostratigraphic scheme of the Silesian Nappe in the Outer Carpathians (after [29-32]).

\section{Geological Setting}

\subsection{General Outline}

The studied section of the upper Albian-middle Cenomanian is a mix of siliciclastic and calcareous deep sea deposits occurring in the Polish part of the Outer Western Carpathians (Figure 1A,B), which comprises several units (nappes and thrust-sheets), regarded as remnants of oceanic basins. They were folded and thrust mainly in the middle and late Miocene (e.g., $[33,34])$ as a result of an oblique convergence between the Eurasian Plate and the Alcapa superterranes (e.g., [35]). The Silesian Nappe is now one of the core nappes of the Outer Carpathians which consists of a succession of the Upper Jurassic through Miocene sediments, mainly siliciclastic deposits of gravity flows (e.g., [36]).

During the Cretaceous to Paleogene interval, the deposits of the Silesian Nappe, predominately deep-water, siliciclastic turbidites (locally debris flow deposits-debrites) were laid down in the Silesian Basin which was a long and deep trough opened (as a result of rifting) along its southern margin (e.g., [36,37]). This basin was bordered on the northeast by the Subsilesian (submerged) Ridge and on the southwest-by the Silesian Ridge [34,36,38].

The late Albian and Cenomanian was a time interval when shallow, wide epicontinental seas located on the European peri-Tethyan shelves, north on the Silesian Basin were the 
places of carbonate sedimentation (e.g., [18,39]) overgrown by lush sponge communities (e.g., [40]). The material originated from the destruction of these sponge assemblages, predominately lithistids (e.g., [41,42]), and carbonate microconstituents were gradually washed away and redeposited into deep marginal basins of the Carpathians, forming wide turbidite bodies in the sea floor of the Subsilesian [24], Silesian [18,22,30] and Skole [43] basins. Currently, extensive spicule-rich turbiditic series containing mixed siliciclastic and calcareous deposits occur in the Outer Carpathian nappes in the Czech and Polish Carpathians and continue further east in the Silesian-Chornohora nappe of the Ukrainian Carpathians (e.g., [44-46]).

\subsection{Lithostratigraphy, Biostratigraphy and Chemostratigraphy}

These mixed siliciclastic and calcareous deposits belong to three lithostratigraphic units of the Silesian Nappe (Figures 1C, 2 and 3A): the upper part of the Middle Lgota Beds (MLB), the Mikuszowice Chert Beds (MCB; representing the Upper Lgota Beds), and the lower part of the Barnasiówka Radiolarian Shale Formation (BRSF).

Previous lithostratigraphic, microfacial and palaeontological investigations showed the main features of these units and their stratigraphic position [21,22,31,32]. These are fine-grained turbidities consisting of detrital material mixed with biogenic particles, which are predominantly siliceous spicules of Demospongiae. This group is represented predominately by orders Lithistida, Hadromerida and Astrophorida [18]. Redeposited material is intercalated with hemipelagic non-calcareous shales (Figures 2 and 3) which include, among the microfossils, only radiolarians and deep-water agglutinated foraminifera (DWAF). The numerous redeposited biogenic grains start to appear in turbidites from the upper part of the MLB but the huge mass of spicule-rich particles and other bio-clasts are the main components of the overlying MCB [21,22,32].

Based on the radiolarian data, the succession studied is mostly correlated with the Holocryptocanium barbui radiolarian Zone (Figure 4), previously distinguished in the pelagic facies of the Pieniny Klippen Belt of the Carpathian domain [47]. The lower limit of this Zone is not specified in the studied deposits. The upper limit is marked by the first occurrence (FO) of Hemicryptocapsa prepolyhedra Dumitrică (the index species of the H. prepolyhedra radiolarian Zone [47], found $3.8 \mathrm{~m}$ above the upper boundary of the MCB (Figure 4). Hemicryptocapsa prepolyhedra Dumitrică is a cosmopolitan species in the Western Tethys, thus, the base of this Zone is a correlation level recognized in various basins of the Carpathian realm $[25,43]$ and corresponds to an interval between the Mid Cenomanian Event 1 and the Oceanic Anoxic Event 2 (discussion in [32,48-50]).

The biotic marker pointing the lower part of the succession studied is the last occurrence (LO) of an DWAF species Plectorecurvoides alternans Noth noted $1.4 \mathrm{~m}$ above the lower boundary of the MCB (Figure 4). The total range of this species delimits the P. alternans Interval Zone [51] commonly used in the Western Tethyan deep-water successions (summary in [52]), which indicates that the MCB lower boundary may correspond to the uppermost Albian. The overlying sediments of the MCB and Barnasiówka Radiolarian Shale Formation belong entirely to the Bulbobaculites problematicus (Neagu) agglutinated foraminiferal Interval Zone (Figure 4). The FO of this index species is close to the base of the MCB.

Combined biostratigraphic and chemostratigraphic $\left(\delta^{13} \mathrm{C}_{\mathrm{org}}\right)$ studies allowed to date these mixed siliciclastic and calcareous deposits enriched in sponge spicules as the latest Albian through the middle Cenomanian, and distinguished the isotope excursions characteristic for this interval [32], as the Albian-Cenomanian Boundary Interval containing the OAE1d, and the Mid-Cenomanian Event containing the MCE Ia, MCE Ib and ?MCE II (Figure 4). The base of the MCB corresponds to the top of OAE1d, whereas the top of this lithostratigraphic unit occurs between the MCE Ib and MCE II. 

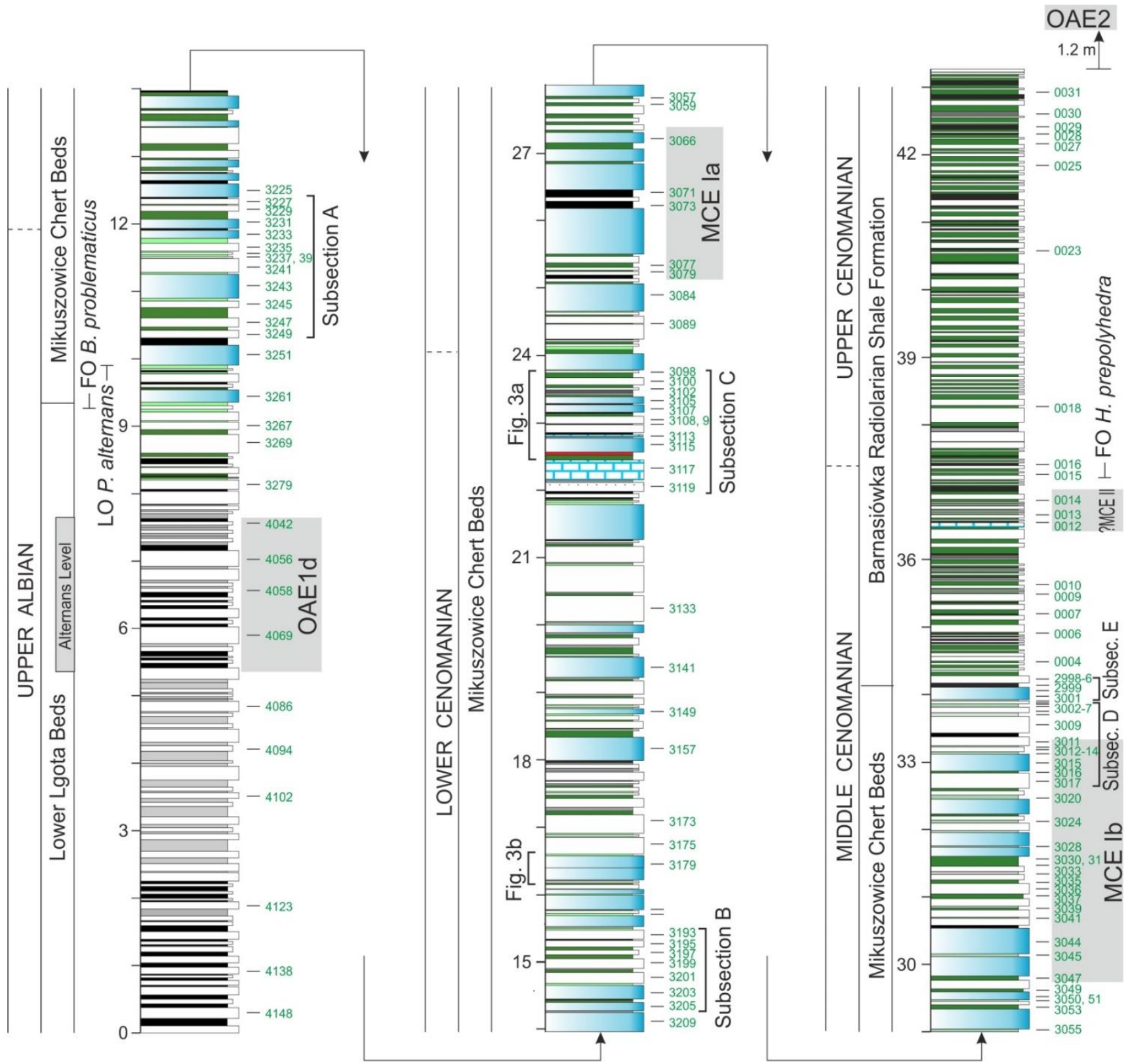

Shale/claystone:

black

grey

dark green

light green

sandstone/mudstone

sandstone with cherts

茞 allodapic limestone

Figure 2. Lithological column of the Barnasiówka-Jasienica section with the position of five subsections (from A to E) studied in detail (microfacial studies in all successive micro-areas in thin sections), and with location of samples analyzed during this study. Correlation of sediments with isotopic events (OAE1d, MCE Ia, MCE Ib, and ?MCE II) is after [32]. 

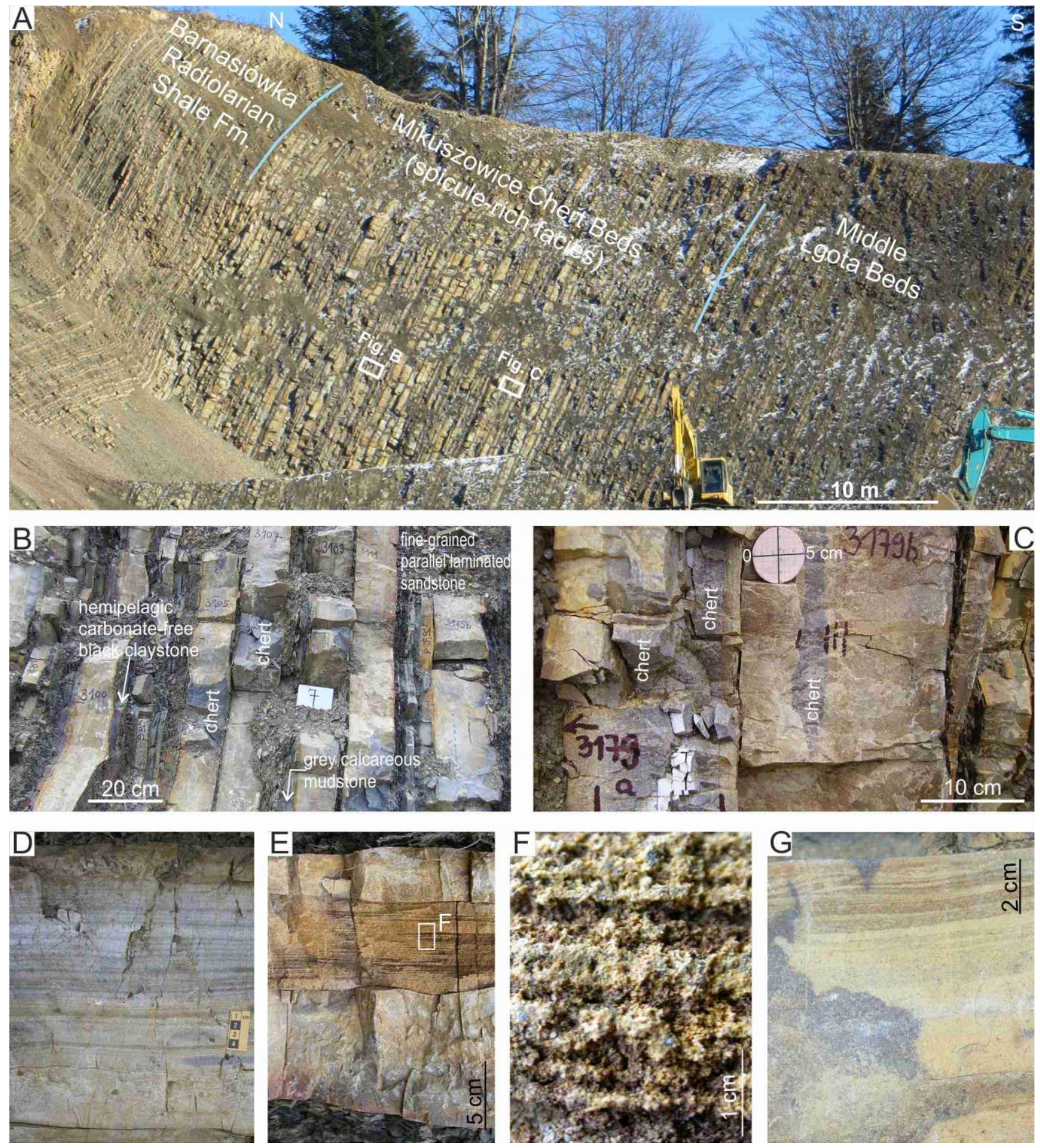

Figure 3. (A) Upper Albian-upper Cenomanian flysch sediments of the Silesian Nappe outcropped in the Barnasiówka-Jasienica quarry, Polish part of the Outer Carpathians (photograph taken in December, 2020). (B,C) Examples of lower Cenomanian turbidite and hemipelagic facies belonging to the Mikuszowice Chert Beds; note numerous occurrence of cherts in fine- to medium-grained sandstone layers; silica originating mostly from sponge spicules. (D-G) Most of the sandstone layers of the MCB contain $\mathrm{T}_{\mathrm{bd}}$ intervals of Bouma sequence, occasionally- $\mathrm{T}_{\mathrm{bc}}$ intervals $(\mathrm{G})$. 


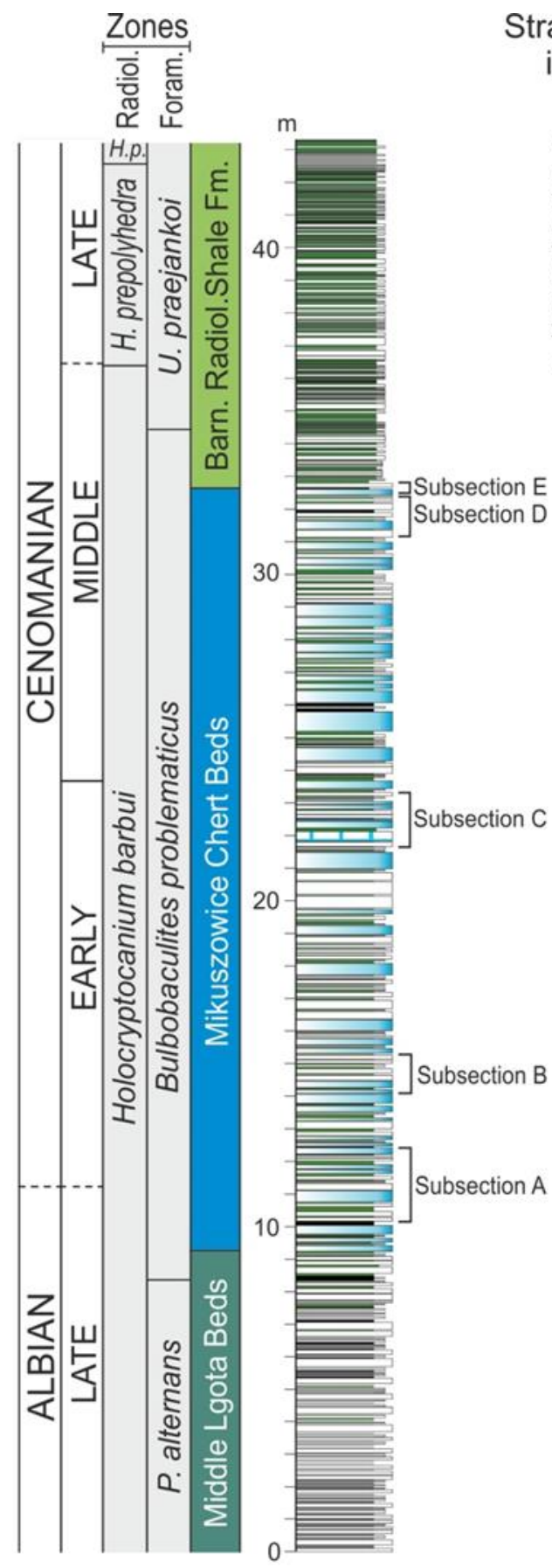

Stratigraphic $\quad \delta^{13} \mathrm{C}_{\text {org }}$
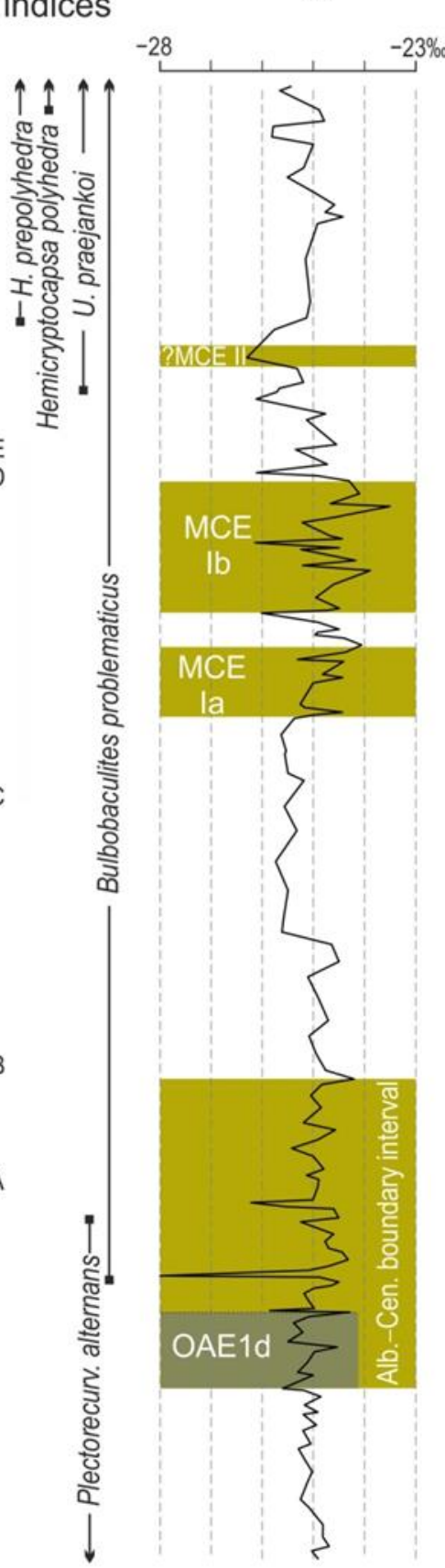

Figure 4. Lithological log of the Barnasiówka-Jasienica section, Silesian Nappe, Outer Carpathians plotted against the main radiolarian and foraminiferal stratigraphic markers, and $\delta^{13} \mathrm{C}_{\text {org }}$ curve containing a range of the main carbon isotope events (after [32]). The position of the subsection studied is also presented. U. praejankoi-Uvigerinaminna praejankoi Agglutinated Foraminifera Zone; H. p.-Hemicryptocapsa polyhedra Radiolarian Zone, H. prepolyhedra-Hemicryptocapsa prepolyhedra Radiolarian Zone.

\section{Material and Methods}

\subsection{Sampling}

The studied succession is outcropped in the central part of the Silesian Nappe of the Western Outer Carpathians (Figure 1B,C), in the Barnasiówka Ridge, and is a part of the Wieliczka Foothills-a physico-geographical mesoregion of Poland, covering a fragment of the Beskidy foreland, located between the Wieprzówka and Raba valleys. The sediments 
are exposed at the Barnasiówka-Jasienica quarry with conducted mining ( $\mathrm{N} \mathrm{49} 49^{\circ} 56.1^{\prime \prime}$ and $\left.\mathrm{E} 19^{\circ} 52^{\prime} 06.3^{\prime \prime}\right), 5 \mathrm{~km}$ west of Myślenice town, and about $35 \mathrm{~km}$ south of Kraków city. The study was based on a detailed, bed-by-bed outcrop investigation and sampling of $43 \mathrm{~m}$-long section (Figure 3A). The MCB ( $25 \mathrm{~m}$ thick) consists of the thickest investigated succession underlying by the MLB (about $12 \mathrm{~m}$ thick during the time of sampling), and overlying by the BRSF (about $15 \mathrm{~m}$ thick).

A total of 300 rock samples has been taken for different studies. The digging and site access permits of these rock samples were not required. All processed rock material (as labeled residue) is stored in the Department of Geology of the Institute of Geography, Pedagogical University of Krakow, Poland.

\subsection{Microfacies Analysis}

Microfacies analysis of the deposits studied has been determined using 126 thin sections of the rocks taken along the whole 43-m thick section. High-resolution microfacies observations, were made lamina by lamina, for the Mikuszowice Chert Beds. The biogenicrich sediments contain numerous planktic biota. They have been made in 41 thin sections related to samples taken continuously along five subsections (A-E; Figure 2). Each of them comprises ca. 1.2-1.8 m thick succession of turbidite and hemipelagic deposits. Counting of the micro-constituent proportions was made according to the method described in [5]. Whole section views were subdivided arbitrary on micro-areas as subsequent fragments of sediment parallel to each other, which vary in thickness from 0.1 to $0.5 \mathrm{~mm}$ and were examined under a light microscope at magnification $50 \times$ (Figure 5). Percentage abundance data of radiolarians and planktonic foraminifera were estimated over the total field of view and estimated using the diagrams of Baccelle and Bosellini [53]. Such counting was made in each of the successive 1750 micro-areas from subsections A-E. Microfacies and microconstituents have been photographed with a polarizing microscope (Nikon Eclipse 100 POL) in the Department of Geology of the Institute of Geography (Pedagogical University of Krakow).

\subsection{Micropalaeontological Analysis}

Radiolarians and planktonic foraminifera were taxonomically recognized and counted from the residues obtained after chemical rock sample disintegration. The occurrence of recognized assemblages in this study has been supplemented by data from previous research carried out in the Barnasiówka-Jasienica quarry before reactivation of its operation in 2015 [21,31,54,55].

Planktonic microfossils were extracted from 161 samples taken along the section. The samples of about $0.3-1 \mathrm{~kg}$ and of different lithologies as siliciclastics, carbonates, and cherts were used during this study. Each sample was first broken into pieces $1-2 \mathrm{~cm}$ across. The following procedures depended on the lithology of the sample. Mudstones and silty shales were soaked in hot solution of Glauber's salt $\left(\mathrm{Na}_{2} \mathrm{SO}_{4}\right)$ and heated, usually several dozen times. In case of marly shale and limestone, microfossils were freed by dissolving the rock matrix in hot acetic acid, by keeping the sample soaked with fully concentrated acid at a maximum temperature of 80 degrees Celsius for 4-6 h [56]. Chert and silicified limestone were treated with hydrochloric and hydrofluoric acids, respectively, according to the procedure described in [57]. After chemical preparation, the samples were washed over a $63-\mu \mathrm{m}$ sieve and dried. The residue was completely picked for microfauna, which was present in residue of 125 samples (Table S1). For taxonomic studies we also used 41 thin sections taken from five subsections for microfacies analysis. 

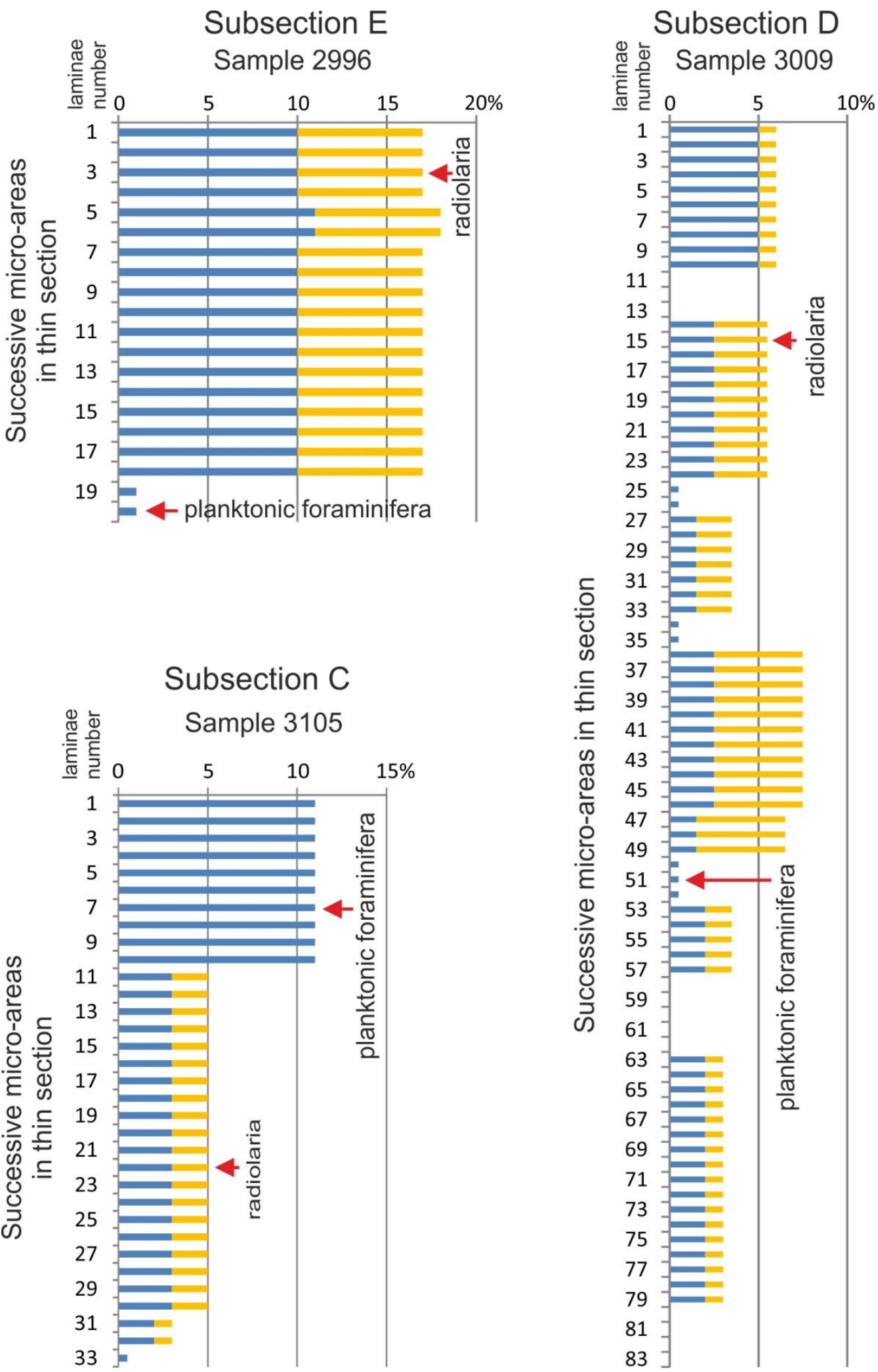

Figure 5. Diagrams showing selected results of micro-areas analysis in subsections. Percentage abundance of radiolarians and planktonic foraminifera was estimated over the total field of view on micro-areas as subsequent laminae which vary in thickness from 0.1 to $0.5 \mathrm{~mm}$. 
Selected specimens were photographed using a scanning microscope at the Institute of Geological Science, Jagiellonian University, Kraków. All micropalaeontological analyses have been made in the Geological Laboratory at the Department of Geology of the Institute of Geography (Pedagogical University of Krakow).

\section{Results}

\subsection{General Sedimentary Features of Turbidites}

The Middle Lgota Beds (MLB) consist mostly of thin- and medium-bedded, siliceous, dark, fine-grained sandstones, intercalated with black, grey, green and spotty non-calcareous claystones (Figure 3A-C). The analysis of carbon stable isotope data [32] showed that the uppermost part of these MLB sequence and the lowermost part of the MCB correspond to the oceanic anoxic event 1d (OAE1d) (Figure 4). The base of this succession with abundant biotic particles, redeposited from peri-Tethyan shelf occurs in the upper part of this carbonisotope unit. It is characterized by increasing admixture of loose sponge spicules which could be visible only in thin sections.

The Mikuszowice Chert Beds (MCB) are composed of $\mathrm{mm}$ to $\mathrm{cm}$-thick siliciclastic to calcareous partly silicified, fine-grained flysch deposits, which represent predominantly $\mathrm{T}_{\text {bde }}$ intervals of the Bouma sequence (Figure 3D-G). The most striking feature of these deposits, visible only in thin sections, is the high content of siliceous sponge spicules. Other biogenic micro-constituents are planktonic and benthic calcareous foraminifera, inoceramid prisms and, sporadically, fragmented coralline algae and echinoid spines. Radiolarians are present in the MCB despite of the later diagenetic remobilization of biogenic silica and formation of bluish chert layers (summary in $[18,22])$. The carbon stable isotope analysis identified the upper part of the MCB corresponding to the Mid-Cenomanian event Ia and Ib (Figure 4) [32,49]. The uppermost part of this unit passes gradually into the lower part of the BRSF which differs from MCB by the lack of chert layers. The lower part of the BRSF (9.7 m thick) consists of thin- to medium-bedded (up to $25 \mathrm{~cm}$ ) calciturbidites and siliciclastic silty and fine-grained sandy turbidites with intercalations of non-calcareous green and black, partly hemipelagic siltstones.

\subsection{Microfauna in Microfacies Record - Content and Preservation}

Analysis of microfacies shows that these deposits are predominantly mud-supported and consist of microfaunal/microfloral allochems, quartz and lithic clasts, micrite, clay minerals and/or dispersed organic matter. Biogenic particles contain planktonic and benthic calcareous foraminifera, radiolarians, deep-water agglutinated foraminifera, and sporadically, fragmented coralline algae, echinoid spines and inoceramid prisms. Diversity of biotic and lithic clasts and their volume in relation to the matrix and cement type allowed to determine various microfacies in these deposits. Four microfacies types are distinguished in the centimeter scale (Figure 6) containing: (1) sublitharenite, (2) spiculites containing predominately spicules of siliceous sponges, (3) biomicrite with predominately foraminifera and/or radiolarians, and (4) hemipelagic siltstones (Figures 6 and 7). 

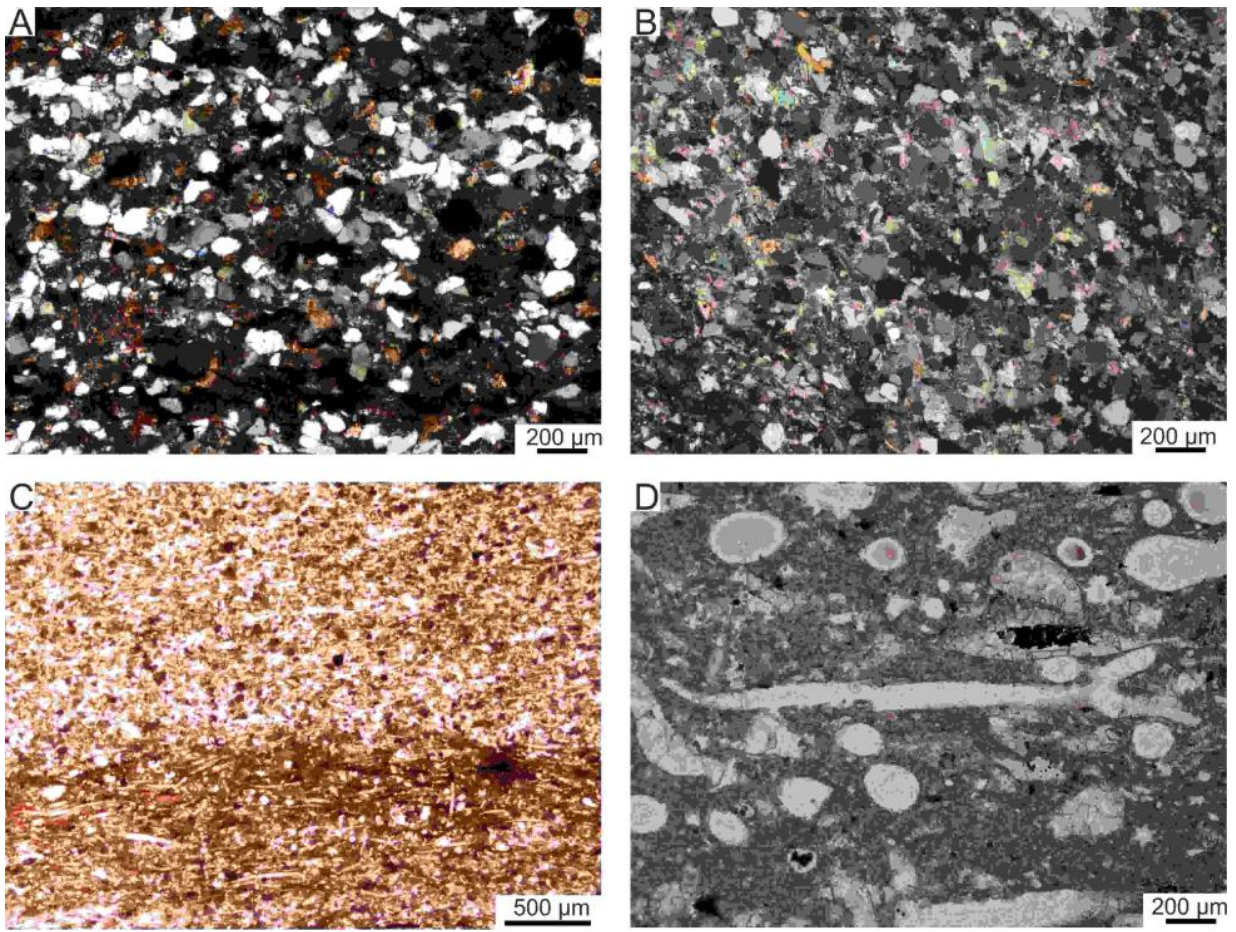

Figure 6. Examples of microfacies dominated by sand-sized particles in the Mikuszowice Chert Beds. (A,B) Sublitharenite (subsection A), (A)—sample J3243, (B)—sample J3226; (C) Spiculite with seams which are matrix-supported and more clayey contains radiolarian skeletons (subsection $\mathrm{C}$ ), sample J3100; (D) Details of spiculite showing different cross-sections of spicules of siliceous sponges which are calcified (subsection C), sample J3105. All photos oriented perpendicular to layering.
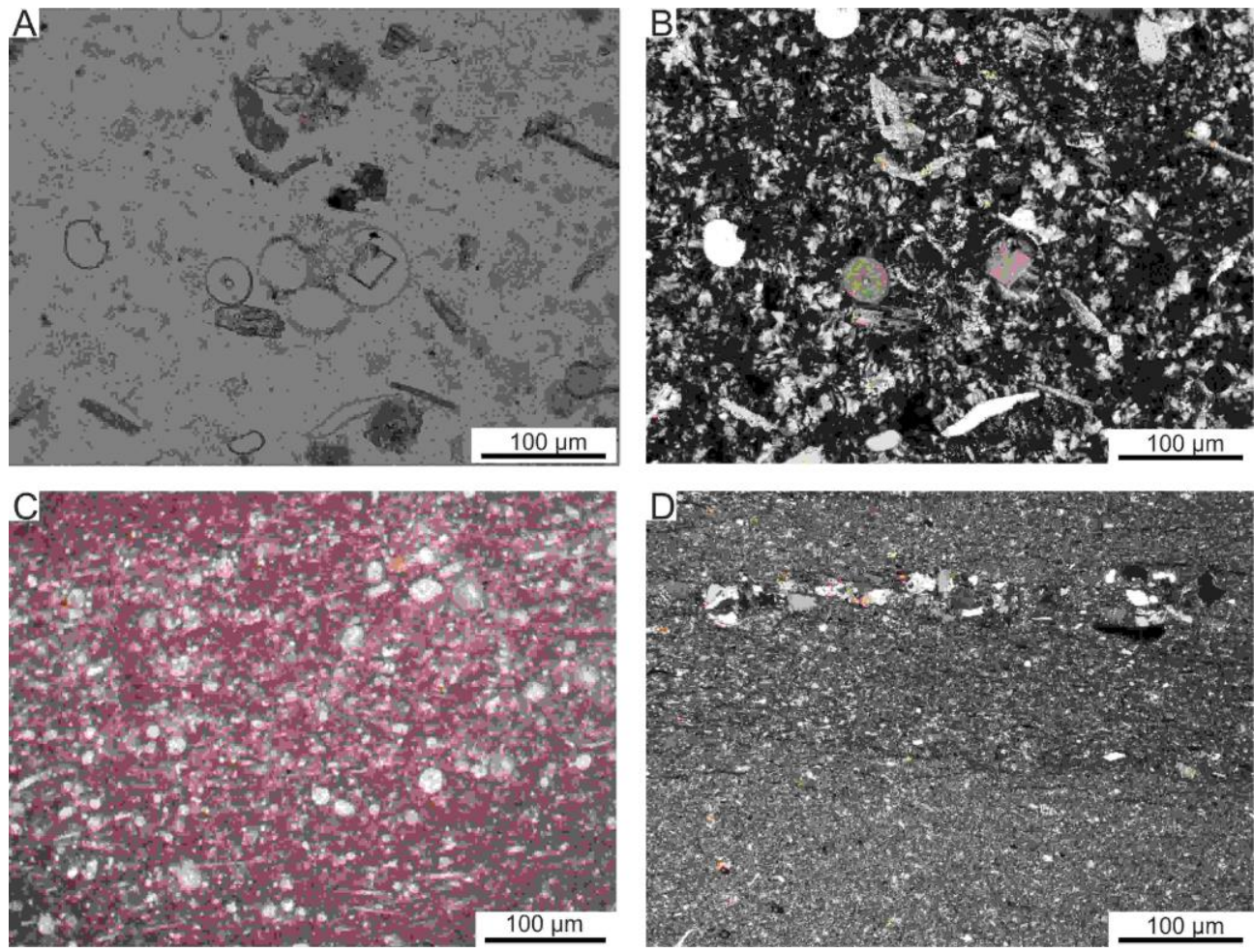

Figure 7. Examples of microfacies dominated by clay- and silt-sized particles in the Mikuszowice Chert Beds. (A,B) Foraminiferal biomicrite (the same view in crossed pollars (B)), partly silicified (subsection B), sample J3205. (C) Radiolarian biomicrite (subsection C), sample J3117. (D) Hemipelagic siltstone (subsection D), sample J3002. All photos oriented perpendicular to layering. 


\subsubsection{Sublitharenite}

This microfacies in thin section view (Figure 6A,B) is composed predominately of quartz (up to $85 \%$ ), usually angular in shape. Radiolarians and planktonic foraminifera content do not exceed $5 \%$ of this microfacies. They are also rarely present in the residuum after chemical disintegration of this lithotype. The specimens of planktic biota present there are very poorly preserved and recrystallized. This rock includes also about $1 \%$ of benthic foraminifera occurring as moulds, usually infilled by calcite cement. Sizes of the tests and skeletons vary between 30 and $150 \mu \mathrm{m}$. Specimens in separated material are moderately to poorly preserved. Among radiolarians, specimens from the family Williriedellidae dominate there (Figure 8). Some species from genus Praeconocaryomma are also present. Among planktonic foraminifera, forms from the genera Hedbergella and Heterohelix were observed (Figure 9).
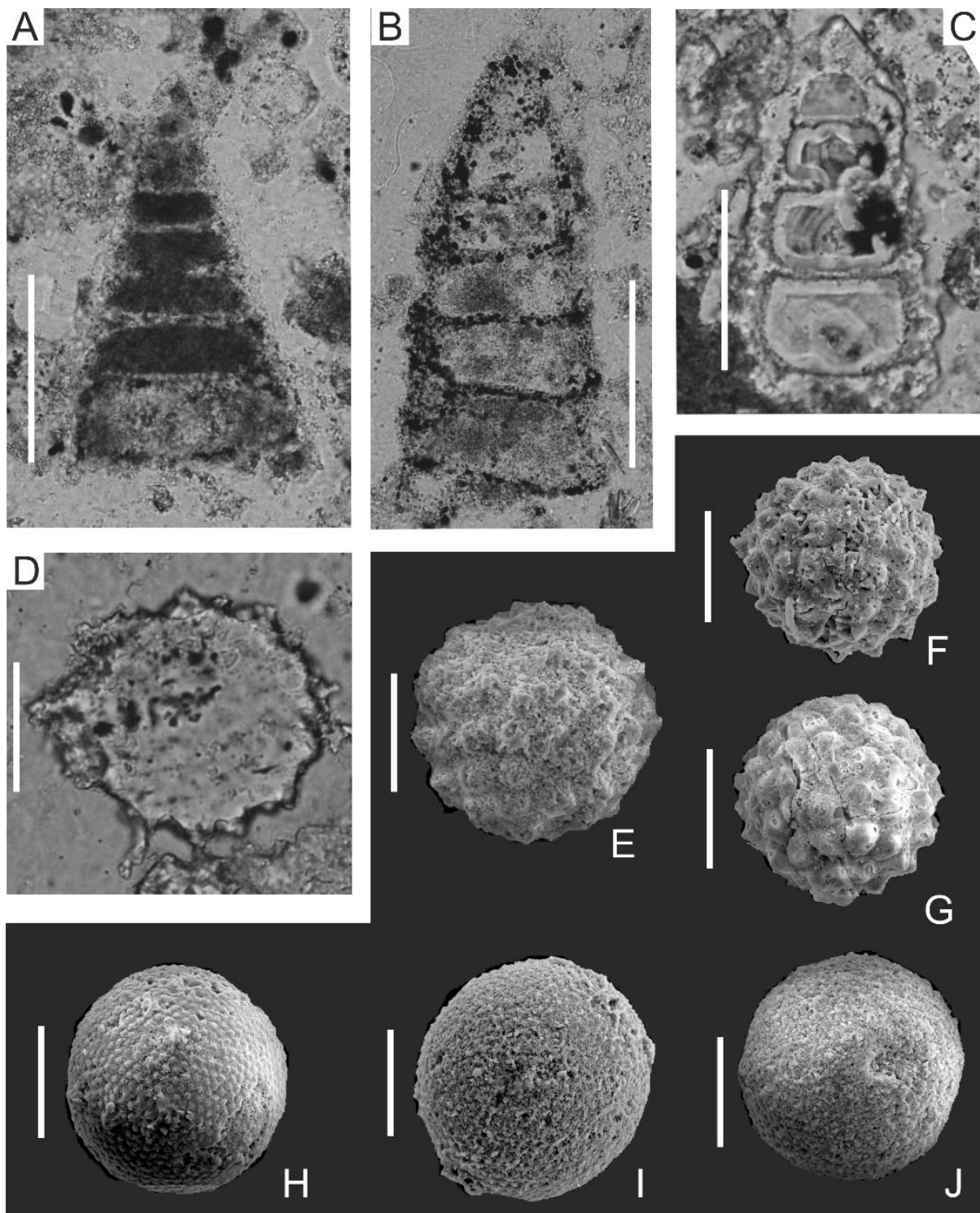

Figure 8. Selected radiolarian taxa from biomicrites (A-D) and hemipelagic claystones (E-J) from the Mikuszowice Chert Beds, Silesian Nappe, Outer Carpathians: (A) Dictyomitra gracilis (Squinabol), sample J3208; (B) Stichomitra communis Squinabol, sample J3001; (C) Xitus spicularius (Aliev), sample J3009; (D,E) Praeconocaryomma lipmanae Pessagno, D—sample J3141, E-sample J3077. (F,G) Holocryptocanium tuberculatum Dumitrică, F-sample J3128, G-sample J3033. (H-J) Holocryptocanium barbui Dumitrică, H—sample J3199, I—sample J3033, J—sample J3020. Scale bar $100 \mu \mathrm{m}$. 

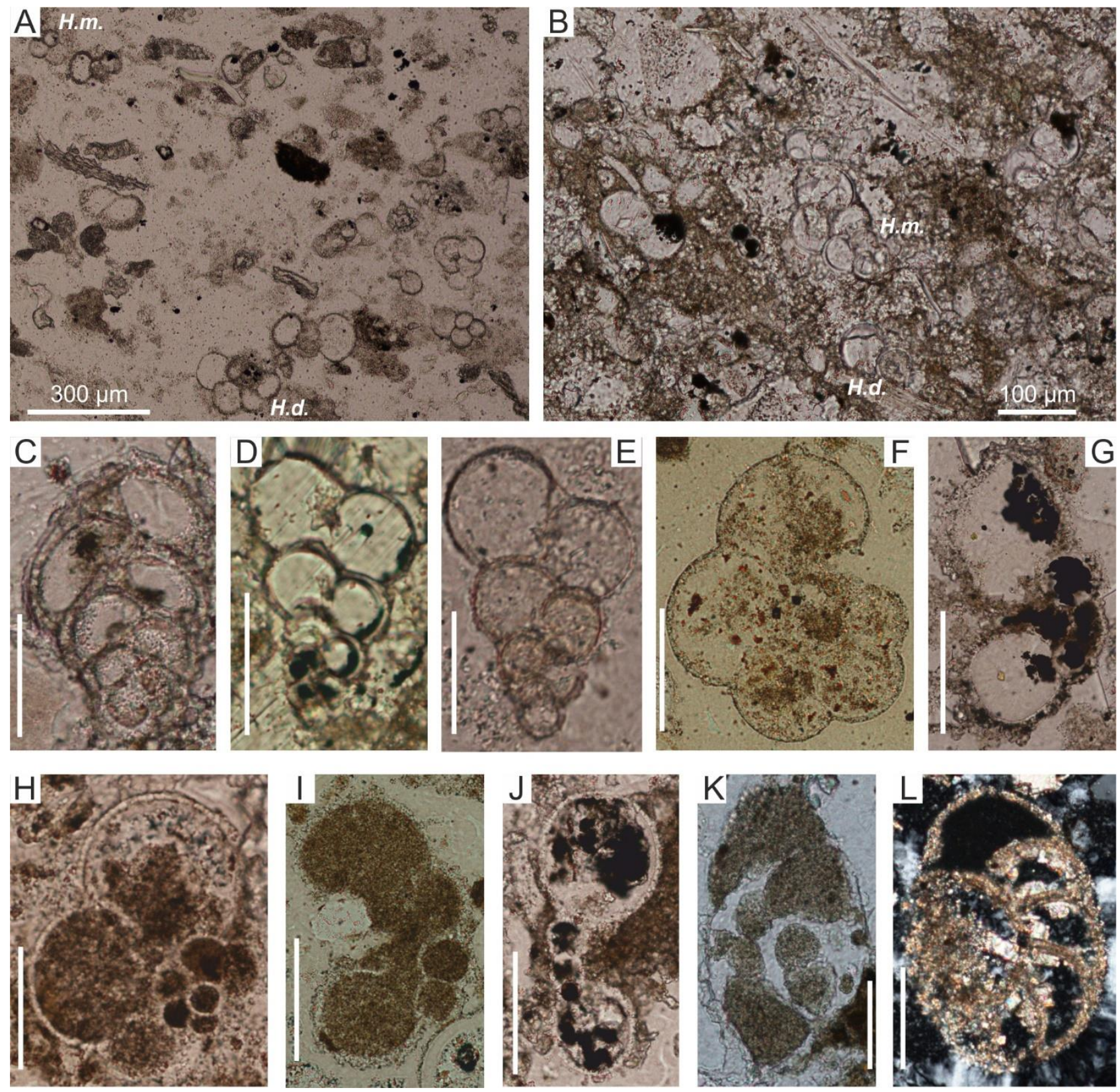

Figure 9. (A,B) Foraminiferal biomicrite dominated by trochospiral forms from the genus Hedbergella (H.d.) and biserial forms from genus Planoheterohelix (P.m); (A)—sample 2998, subsection E; (B)sample 3115, subsection C. Redeposited planktonic foraminifera from biomicrites of turbidite layers in the Mikuszowice Chert Beds. (C-E) Planoheterohelix moremani (Cushman), (C)—sample J3105, (D,E)—sample 2996. (F-J) Hedbergella spp., (F)—sample J3205, (G)—sample J3001, (H)—sample J3015, (I)—sample J3199, (J)—sample J3208. (K,L) Rotalipora/Thalmannammina sp., (K)—sample J3227, (L) -sample J3001. Scale bar $100 \mu \mathrm{m}$ for figures (D-L).

\subsubsection{Spiculite}

Spiculite microfacies (Figure 6C,D) contains up to $90 \%$ of spicules of siliceous sponges which are usually calcified. Other micro-constituents are foraminifera (planktonic and benthic), radiolarians, and rare detrital grains of quartz and glauconite. This type of sediment could be chaotically packed or micro-constituents might be arranged in parallel laminae on millimeter scale, separated by less than $1 \mathrm{~mm}$ thick seams. Those seams which are matrix-supported and more clayey consist up to $30 \%$ of radiolarians. Microfossil tests and skeletons within the seams are partly filled with spheroidal grains of opaque minerals, 
3-10 $\mu \mathrm{m}$ in diameter being pyrite framboids. Better preserved specimens of radiolarians belong to the family Williriedellidae (Figure 8), while the planktonic foraminifera belong to the genera Hedbergella and Heterohelix (Figure 9).

\subsubsection{Foraminiferal and Radiolarian Biomicrite/Biosparite}

Microfacies that contain predominately foraminiferal tests and/or radiolarian skeletons (Figures 7A-C, 8 and 9) occur in the whole succession studied but become more frequent in the upper part of the MCB. Pure foraminiferal biomicrite/biosparite consists mostly of benthic and planktonic foraminifera, but the calcareous benthic foraminiferal tests prevail, reaching a maximum content of up to $30 \%$. In some of the laminae planktonic species dominate; they belong mostly to hedbergellids. There is a very low radiolarian skeletons admixture in this type of microfacies (up to 1\%), but radiolarians are commonly present in the radiolarian biomicrite/biosparite microfacies. A few such layers, up to $15 \mathrm{~cm}$ thick, occur also in the upper part of the MCB. Macroscopically, these layers consist of dark-grey allodapic limestone corresponding to $\mathrm{T}_{\mathrm{d}}$ intervals (Figure $7 \mathrm{C}$ ). The grain framework of this rock consists exclusively of biogenic components, which makes up 10 to $60 \%$ of the whole rock. Radiolarians are present in these rocks as voids after skeletons, secondarily filled by sparry calcite (Figure 7C). Other biogenic components are tests of planktonic foraminifera which are in the minority. Radiolarians vary in size from 30 to $300 \mu \mathrm{m}$. Foraminifer tests are very small, usually less than $50 \mu \mathrm{m}$. Rare forms with single keel among the planktonic foraminifers (Thalmannamina/Rotalipora/Praeglobotruncana) were observed in some foraminiferal biomicrites.

\subsubsection{Hemipelagic Siltstone to Claystone}

Hemipelagic siltstone to claystone (Figure 7D) contains radiolarians and deep water agglutinated foraminifera. Radiolarian skeletons are present in each type of clay layers. Their total abundance in green hemipelagites fluctuates from 0 to $40 \%$ while, in black and grey pelagites do not exceed $10 \%$. Radiolarian skeletons are very small, with the widest dimension usually below $30 \mu \mathrm{m}$. Larger skeletons are rare. Radiolarians are moderately to poorly preserved. Most skeletons have been recrystallized and are now replaced by pyrite or Fe-oxides resulting in the obliteration of their external and internal wall structures. Only ca. $20 \%$ of skeletons are identifiable; Holocryptocanium, Cryptamphorella and Praeconocaryomma predominate among the recognizable individuals.

\subsection{Analysis of Relative Abundance of Radiolarian Assemblage}

For this analysis, samples taken along the entire section every few to several centimeters were used. Radiolarian assemblages are the most diversified among planktonic biota found in thin sections as well as in rock residue left after rock dissolution. In the section studied, the samples yielded in total a relatively well-preserved radiolarian assemblages consisting of 26 species and corresponding to 18 genera (Table S1; Figure 8). The most frequent species belong to the genera Holocryptocanium, Cryptamphorella and Hemicryptocapsa, among the nassellarids, and the genus Praeconocaryomma among the spumellarids. The order Entactinaria is represented by one genus (Quinquecapsullaria) which contains two species. The nassellarian species that belong to the family Williriedellidae are the main components of the radiolarian assemblages. Holocryptocanium barbui Dumitrică, Holocryptocanium tuberculatum Dumitrică and Praeconocaryomma lipmanae Pessagno are the most common species, comprising up to $90 \%$ of the total microfaunal assemblage. However, the majority of radiolarian species (23 taxa) in the whole assemblage belongs to rare species, which do not exceed $1 \%$ in relative abundance.

Identified radiolarians have been classified into radiolarian ecological groups defined for the Cenomanian Western Tethyan deposits [50] (Table S1). Thirteen species represent the B supergroup which were interpreted as deep dwelling taxa (Figure 10) and which preferred nutrient-rich eutrophic conditions. Amongst the species of this group, Holocryptocanium barbui Dumitrică dominates quantitatively, comprising up to 85\% 
of the total microfaunal assemblage. This species is commonly present in spiculites and hemipelagic and pelagic claystones. The frequency of $H$. barbui Dumitrică coincides with radiolarian dominance and culminates within the upper part of the MCB (32\%) and in the lowermost part of the BRSF, with the maximum value of $75.5 \%$. Identified genera that belong to radiolarian ecological groups [50] which could tolerate increased nutrient content are Squinabollum fossile (Squinabol) (group B2), Diacanthocapsa ovoidea Dumitrică (B2), Dictyomitra montisserei (Squinabol) (B2), Cryptamphorella conara (Foreman) (B2), Xitus mclaughlini (Pessagno) (B5), Thanarla veneta (Squinabol) (B5) and Holocryptocanium geysersensis Pessagno (B6). Ten species have been classified to the radiolarian ecological supergroup E. This group assembled species which lived predominately in surface waters and preferred oligotrophic conditions (Figure 10).
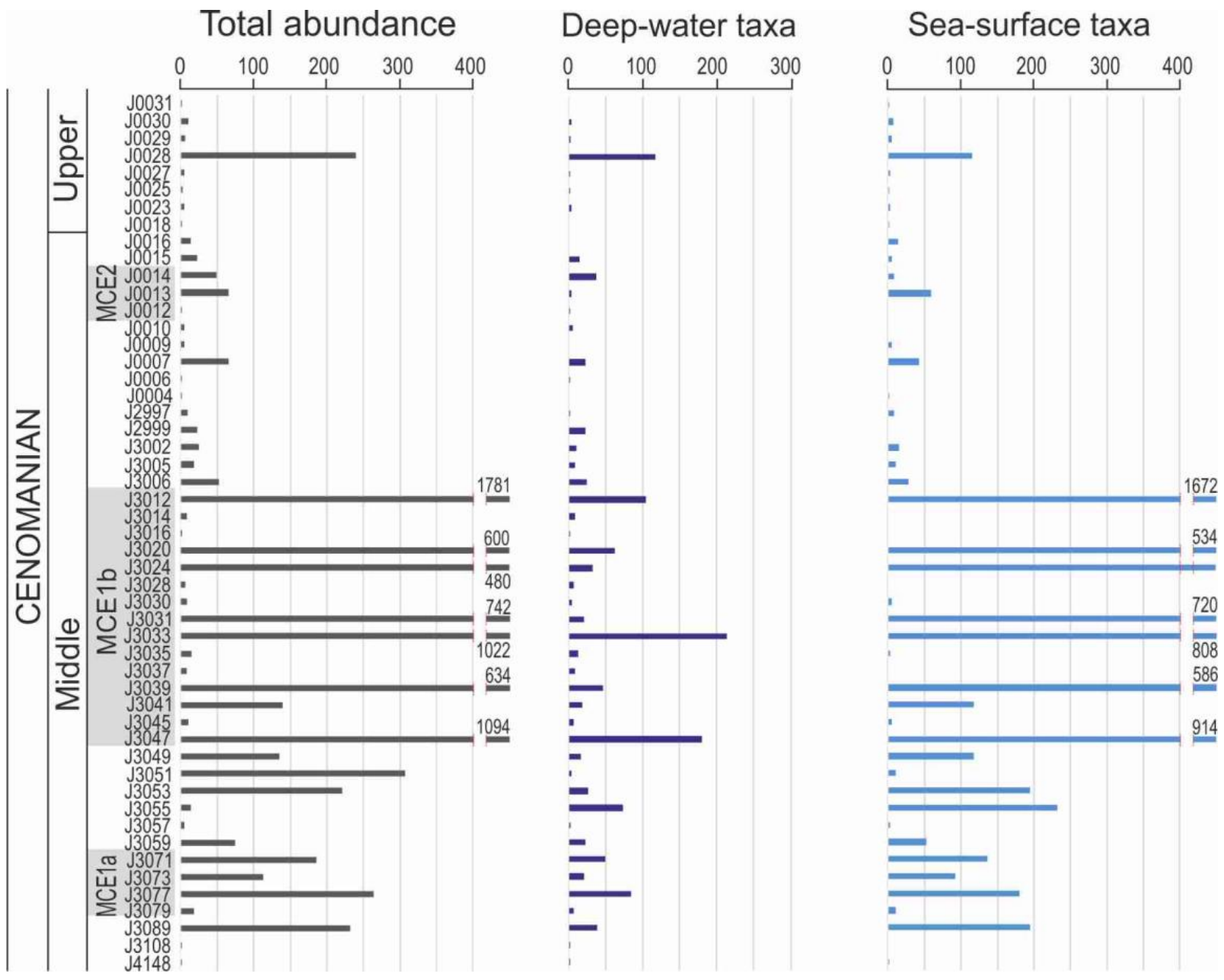

Figure 10. Abundance of two groups of radiolarian taxa, related to depth habitat, interpreted for the middle-upper Cenomanian of the Silesian Nappe, Outer Carpathians.

Spumellaria is less frequent than Nassellaria in the studied assemblage. It composes 20 to $50 \%$ of the total number of radiolarian specimens. The species belong mainly to two families: Actinommidae and Hagiastridae. Hagiastrids were probably symbiont-bearing species living in oligotrophic conditions [5,15,50]. Representatives of the family Actinommidae, such as Praeconocaryomma lipmanae Pessagno are the most frequent, with the maximum value up to $60 \%$ of the total assemblage. This species (E3 ecological group) could tolerate increased nutrient input but preferred an open marine oligotrophic environment [50]. Species such as Gongylothorax siphonofer Dumitrică and Hemicryptocapsa tuberosa Dumitrică (NC group) are rare in the Tethys, but are known from the Carpathian basins [24]. 


\subsection{Qualitative Analysis of Planktonic Foraminiferal Assemblages}

Planktonic foraminiferal assemblages are poorly diversified among planktonic biota found in thin sections. The samples yielded in total relatively well-preserved tests consisting of 9 genera (Table S1) (Figure 9). Their species affiliation is difficult to determine due to the limited number of cross sections, especially for single forms visible in thin sections of the rock. Nevertheless, the most frequent are low trochospiral forms belonging to hedbergellids; mainly from species Muricohedbergella delrioensis (Carsey), subordinaryM. planispira (Tappan), and Clavihedbergella simplex (Morrow). They are associated by biserial forms belonging to heterohelicids from species Planoheterohelix moremani (Cushman). Other planktonic foraminifera have been determined as single specimens representing Guembelitria cenomana (Keller), Globigerinelloides ultramicrus (Subbotina), Whiteinella baltica Douglas and Rankin, Praeglobotruncana sp., and rotaliporids. The latter group contains taxa characteristic of the Cenomanian (?Thalmanninella apenninica (Renz), Th. greenhornensis (Morrow), Th. reicheli (Mornod), Rotalipora cushmani (Morrow)).

The largest content of planktonic foraminifera among bio- and lithogenic components in turbidites characterizes biomicrites that have a character of wakestones. They are accompanied by numerous benthic foraminifera, mainly of the genera Gavelinella, Lingulogavelinella, and Gyroidinoides, as well as individual calcareous algae and fragments of echinoderms. Single tests (larger in size) are also found in spiculites and sublitharenites. Single foraminifera were also found in claystones constituting the $T_{e}$ element of the Bouma sequence in turbidites.

\subsection{Percentage Quantity of Planktonic Microfossils}

The percentage quantity of radiolarians and planktonic foraminifera on a background of all microfacies constituents have been counted in all of the 1750 micro-areas from selected subsections (A-E) in the section studied (Figure 11). The radiolarian never exceeds values of $3 \%$ in the subsections A-C. In the subsection D, their content increases up to $5 \%$ in samples corresponding to the MCE Ib deposits. Above this event, radiolarian quantity increases gradually, reaching a maximum value of $7.5 \%$ in the subsection $\mathrm{E}$.

Planktonic foraminifera are a minor component of turbidites in the studied succession, and they are absent among hemipelagic deposits. The lowest values do not exceed $5 \%$ are noted in micro-laminae of subsections A and B. The higher values (up to 10\%) are observed in the subsections $\mathrm{D}$ and $\mathrm{E}$. The maximum quantity of $30 \%$ is noted in the middle part of the subsection $\mathrm{C}$. The increased amount of planktonic foraminifera occurs also among the redeposited particles in the sediments corresponding to the OAE1d and to the younger part of the MCE Ib. 


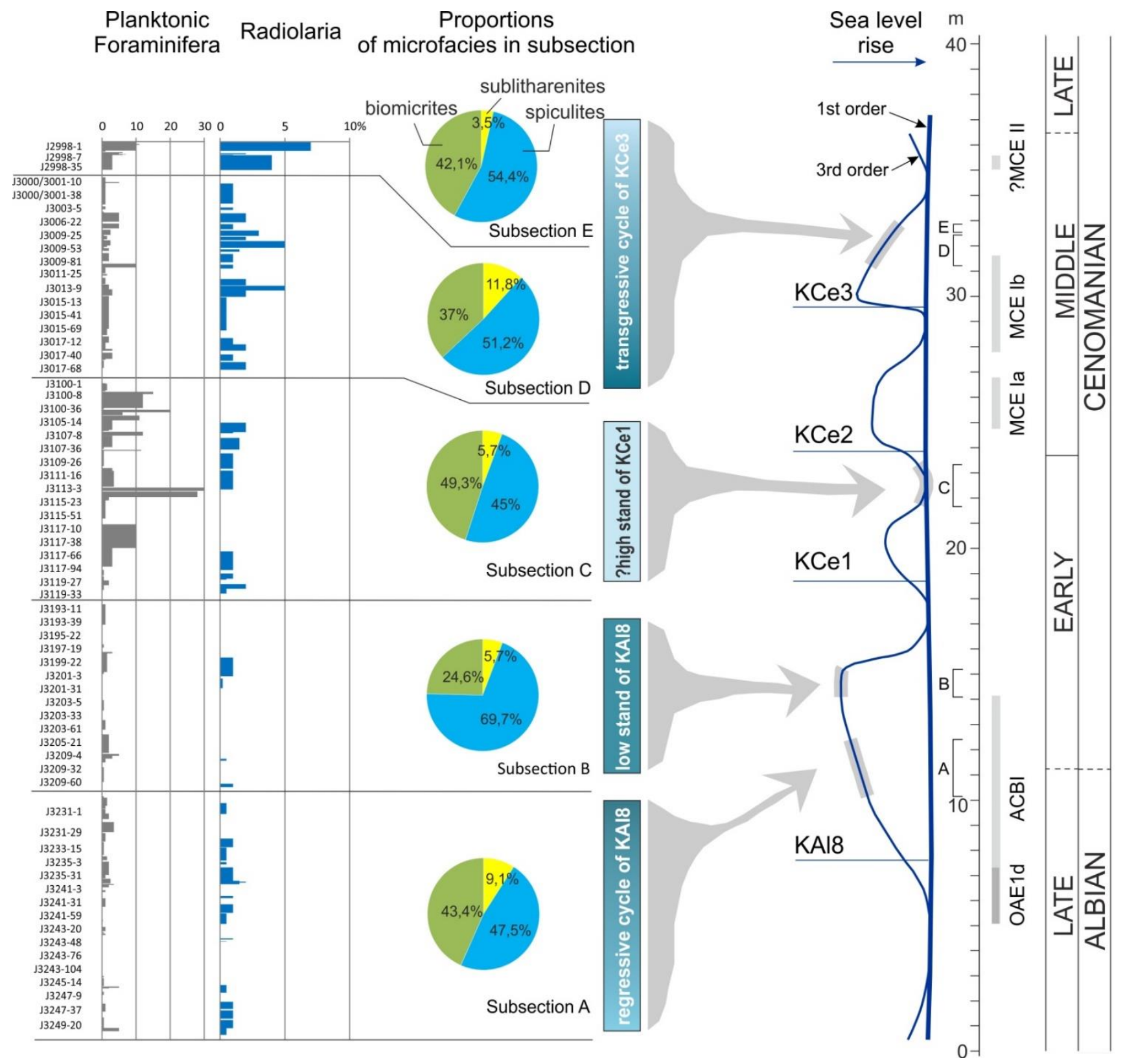

Figure 11. Changes in planktonic microfossils and other components of sandstones presented in the studied segments of the lower-middle Cenomanian sediments of the Silesian Nappe, Outer Carpathians in relation to eurybathic/eustatic cycles sensu Haq [1]. Note that the correlation of the section studied with the sea-level curve is presented after [32].

\section{Discussion}

\subsection{Record of Sea Level Change}

Our previous studies of the age of these sediments, based on analyses of carbon stable isotopes and micropalaeontological data, mostly related to abundance of sponge spicules [32] showed that the beginning of mixed siliciclastic and calcareous turbidites sedimentation, coinciding with the onset of increased supply of sponge spicules to the Silesian Basin, corresponds to the OAE1d. On this basis, we interpret that the sediments of the subsection A, partially corresponding to the youngest phase of the OAE1d, were accumulated at the beginning of a global regressive event KAl8 sensu Haq [1]. The proportion of microfacies, and above all the high content of biomicrites (on average 43.4\%; Figure 11), indicate a relatively high sea level during the redeposition of calcareous micro-constituents 
from the shelf. This suggests that these sediments represent the early lowstand systems tract. Consequently, the overlying sediments of the subsection B are interpreted as accumulated during the maximum of regression, related to the same KAl8 sea-level cycle. This is evidenced by the particularly high content of spiculites among microfacies in sandy-silty turbidites $(\sim 70 \%)$, the highest in the entire succession studied (Figure 11). Additionally, the time interval that covers the accumulation of sediments from subsections $\mathrm{A}$ and " $\mathrm{B}$ " could correspond to the worldwide first-order regression cycle (discussion in [32]).

In relation to the third-order sea-level cycles, sediments of the subsection $\mathrm{C}$, which represent upper lower Cenomanian (discussion in [32]), are interpreted as accumulated during sea-level highstand coinciding with the well-developed calcareous production on the shelf.

The highest part of the succession studied which contains subsections D and E marks the termination of accumulation of mixed siliciclastic and calcareous deposits which took place between two oceanic events, the MCE Ib and MCE II [32]. The detailed correlation is indicated on the upper part of the Acanthoceras rothomagense ammonite Zone, in the upper part of the middle Cenomanian. Such stratigraphic position of both subsections suggests that they coincide with the $\mathrm{KCe} 3$ eustatic event. These intervals mark also the gradual transgression within the $\mathrm{KCe} 3$ eustatic event, which is part of the world's first-order transgression [1] (Figure 11).

\subsection{Microplankton Content in Relation to Sea Level Changes}

The study of radiolarian and planktonic foraminifera occurring in various microfacies within the sequences of turbidite layers or in hemipelagic sediments (the later only for radiolarian skeletons) shows changes in their volume and taxonomic composition in relation to identified episodes of sea-level stand. This is because each of these two groups may react on environmental factors by increasing the number of specimens or completely disappearing. Referring to contemporary plankton communities and those known from the Cretaceous strata, the radiolarian and planktonic foraminiferal fluctuations could correspond to the chemistry and physical properties of the water column and nutrient availability, partly associated with sea-level changes, especially in a marginal part of the basins (e.g., $[4,58])$.

\subsubsection{Planktonic Foraminifera Environmental Signal}

In modern environments that constitute the background for the interpretation of the studied fossil communities, some morphological features of planktonic foraminifera, such as test shape, occurrence of spines, wall structure including size and spatial density of pores, are partly related to adaptation (e.g., [59,60]). The distribution of this group of plankton is controlled mainly by temperature, salinity, trophic conditions, and additionally - by sunlight, and predation in the upper water column (e.g., [61-63]). They all have an influence on water depth preference for particular species, which shifts during ontogeny, and seasonal preference (e.g., [64-66]). The relationships described above were used in palaeoecological models for Cretaceous groups of planktonic foraminifera, taking into account their water depth habitat. Small, globular (Globigerina-like) forms have been included to the shallow-dwelling assemblage, whereas large, flattened taxa with developed ridge (Globorotalia-like) were attributed to environment with greater depths (e.g., [67-69]). This model had also biogeographic implication, that is, shallow-dwelling forms should dominate in the Cretaceous epicontinental seas, whereas more diversified assemblages containing the deep-dwelling taxa should represent pelagic setting (e.g., [70]). Nevertheless, further analysis of planktonic foraminiferal assemblages using oxygen isotope studies (summary in [71]) showed changes in depth preferences for many taxa during the late Albian and early Cenomanian. This concerns a rapid adaptation across the AlbianCenomanian transition (ACT) of Rotalipora (Thalmanninella)-like taxa (Th. globotruncanoides (Sigal), Praeglobotruncana stephani (Gandolfi)) to living at a surface habitat [71] and the decline of surface-dwelling Paracostellagerina libyca (Barr). This vertical migration to greater 
depths occurred also in the early Cenomanian within the Hedbergella delrioensis (Carsey). The changes in adaptive strategy may, at least in part, be related to collapse of the upper water column stratification around the OAE1d, suggested in [72]; however, the reasons for this could be varied including warming of intermediate [73] or cooling of surface water during an interval that started at the ACT [71].

The suggestion about the depth-reorganization of planktonic foraminifera after the OAE1d has been proposed based on the data from pelagic environments, mostly from the oceanic settings.

When we compare the proportions in the abundance of different planktonic foraminiferarich rocks derived from the epicontinental environment of the seas associated with the Tethys, another change can be seen in the sediments of the early and middle Cenomanian. An example of this is the Annopol section, known as "lagerstatte", which since the late Albian was connected to the Carpathian part of the Tethys via the Lviv Gate [74]. In the glauconite marls of the lower Cenomanian, rich in foraminiferal plankton, the abundance of small, globular forms decreased compared to the upper Albian, with a very slight increase in the abundance of high trochospiral forms with keel and pseudo-keel [75]. This could indirectly be evidence of thermal changes in waters in the early Cenomanian, however, a reduction in the sea level should also be taken into account here. The latter is indicated by the reversal of the plankton-benthos ratio at the Albian-Cenomanian Boundary Interval. In the lower Cenomanian, the proportion of limestone foraminifera benthos is twice that of planktonic foraminifera. Such plankton-benthos ratios have been documented from many profiles from epicontinental seas where a drop in sea level took place (discussion in [7]).

The reference of the abovementioned bathymetric models to the observed changes in redeposited assemblages of planktonic foraminifera in the studied upper Albian-middle Cenomanian succession is extremely difficult due to the low number of tests. However, we are trying to identify these changes in relation to the taxonomic composition and trends visible in the composition of foraminiferal assemblages. The dominance of Hedbergella-like forms in the entire studied succession, accompanied by biserial Planoheterohelix moremani (Cushman) is a typical record for this time interval, known from both pelagic and neritic zones. The low content of P. moremani (Cushman), an oligotrophic form (e.g., [76]), the episodic occurrence of triserial Guembelitria cenomana (Keller) reflecting shallow marine stressful environment (e.g., $[77,78])$, the lack of planktonic foraminifera bearing elongated chambers which were found very close to the OAEs sediments (e.g., [79]), and the lack of significant differences in the size of the tests in all forms rather excludes the presence of extreme or variable surface water conditions in the shelf sea.

Only two parameters are worth discussing here, i.e., the charts showing the change in the abundance of planktonic foraminifera in turbidite sediments and diagrams of changes in the percentage content of biomicrites in these facies. We interpret both elements in the context of spatial and temporal range of pelagic/neritic zone, which are related to abundance of nutrients and dissolved oxygen, water temperature, salinity and, above all, the depth of the shelf bottom affecting life of planktonic biota.

Characteristic here are (Table S1): (1) a small content of planktonic foraminifera in the succession corresponding to the OAE1d (with one positive peak), (2) almost complete lack of it in the succession above the OAE1d and in the lower part of the Lower Cenomanian, (3) the increase in the content of this group in the lower part of subsection C, which also contains layers of allodapic limestones (uppermost part of Lower Cenomanian), as well as (4) their slight increase in turbidites above the MCE 1, where the proportion of biomicrites is also increasing.

The record of slightly enhanced content of small, globular (Hedbergella-like) forms in sediments corresponding to the OAE1d may be result of an increase in sea surface temperature (SST). Such increase of SST during the early and middle phases of the OAE1d was documented both based on planktonic foraminiferal $\delta^{18} \mathrm{O}$ data from the western subtropical North Atlantic (Blake Nose at ODP sites 1050 and 1052; [80]), and calcareous nannoplankton data (Rhagodiscus asper Stradner abundance, calibrated with TEX ${ }^{86}$ SSTs) 
from the deep carbonate platform in the Western Tethys (Umbria-Marche; [81]). One more factor should be added here, which favored the growth of planktonic foraminifera on the peri-Tethyan shelf, even if by increasing its area, i.e., the maximum of transgression during third-order eustatic level corresponded to the KAl8 cycle of Haq [1].

The almost complete lack of redeposited planktonic foraminifera in turbidites with the lowest content of biomicrite microfacies in the subsections A and B which correspond to the Albian-Cenomanian transition and the lower Cenomanian (without its upper part) is interpreted as the record of regression cycles of KAl8. We used here as a rule of thumb that the plankton/benthos ratio is a proxy reflecting the depositional water depth or distance to the coast (or both; e.g., [82,83]). While the increase in the content of redeposited planktonic foraminifera occurring in the lower part of the subsection $C$, associated by layers of allodapic limestones is probably related to the transgression cycles during the early Cenomanian (KCe1). Alternatively, it represents eurybathic sea-level shift, as a product of both local vertical movements and eustasy.

The abundance of redeposited planktonic foraminifera across the MCE Ia and MCE $\mathrm{Ib}$ is low and begins to rise above these chemostratigraphic events. The same trend was described from pelagic sediments in the Western Tethys (Umbria-Marche Basin; [84]), where taxonomic changes containing increases in the proportion of opportunistic taxa and round chambered pustulose forms while a reduction of the the number of K-mode specialists occurred just above the MCE.

\subsubsection{Environmental Signal from Radiolarian Distribution in Water Column}

Differentiation of radiolarians in the Carpathian deposits are generally low. It is a clearly visible trend if we compare the differentiation in the studied deposits of the Silesian Basin (26 species) and the differentiation in sediments from this time period in other basins of the Outer Carpathians, such as the Subsilesian and Skole basins (for comparisonsee $[24,43])$. A similar trend is visible in the basins of the Inner Carpathians, such as the Zliechov Basin [25,26], and in the Branisko [85] or Niedzica [23] subbasins, which were part of the Pieniny Klippen Basin. In all these locations, the number of identified species of radiolarians does not exceed fifty. At the same time, in deposits from the same age range but from the Umbria-Marche area located closer to the equator, the number of species present in these deposits is almost 200 (e.g., [50]). Such a difference in the number of species in radiolarian communities could result from the geographic location of the Carpathian basins, located more to the north in relation to the Umbria-Marche Basin or from the circulation of ocean currents carrying cooler waters [50]. In the Carpathian basins, which are generally deep, the presence of radiolarians in the sediment was certainly related to physical features of the water column, but also to a large extent by taphonomic factors [86]. However, the fact that individual species belong to different ecological groups makes it possible to use this taphonomically depleted assembles for environmental interpretations.

Low radiolarian diversity coupled with a high frequency of single taxon occurrence, which is observed in the Carpathian basins, might point to a period of the high nutrient content in the water column. Such tendency might be analogous to the modern oceans, where radiolarians tend to be less diverse in highly productive than in oligotrophic regions, although radiolarians are abundant then (e.g., $[87,88])$. In the studied deposits from the Silesian Basin, the radiolarian content strongly increases in the uppermost part of the MCB and BRSF, which corresponds to a transgressive trend toward the KCe3 event. Amongst the identified taxa, species of the genus Holocryptocanium dominates quantitatively comprising up to $85 \%$ of the total microfaunal assemblage. It suggests that the rounded shape of skeleton of this species belonging to the family Williriedellidae and their thick wall of abdominal chamber [89] favored their preservation even within redeposited material, however, their quantity linked to production in the water masses must have played the main role in their abundance. Holocryptocanium barbui Dumitrică is the dominant species in the studied assemblage. This species represents the radiolarian ecological group B (see [50]) that assembled species recognized as deep-dwelling forms. It also belongs to the subgroup 
B3 sensu [50] which contains only two radiolarian species preferring nutrient-rich waters with possible phosphorus-rich conditions [50]. There is a clear tendency in the investigated sediments that the rocks containing a large abundance of $H$. barbui Dumitrică species are primarily pelagic or hemipelagic sedimentation, while in biomicrites and spiculites derived from the shelf, $H$. barbui Dumitrică species are extremely rare, occurring only in a single sample from the subsections D and E corresponding to the interval of sea-level rise. Such a distribution of $H$. barbui Dumitrică individuals in the studied deposits confirms that this species occurred in the Silesian Basin as deep-dwelling form that lived probably below the thermocline, where waters rich in nutrients (phosphorus) accumulated. The numerous occurrences of H. barbui Dumitrică in the lower to middle Cenomanian rocks testifies to the continuous occurrence of such conditions at that time. On the other hand, in the lowest part of the section studied including the sediments of the uppermost Albian and the lowest part of the lower Cenomanian, there is a group of radiolarians with a small content of species of H. barbui Dumitrică. This has appeared to be the result a lower saturation with nutrients in the deeper zone of this basin and no general conditions for the existence of radiolarian plankton.

Another trend in the occurrence of the ecological subgroup B3 is visible in the upper part of the MCB and the lower part of the BRSF (subsections D and E). The biomicrites and spiculites occurring here come from the redeposition of the material from outer shelf and upper slope of the Silesian Basin during the rising sea level in the middle Cenomanian. The increase of $H$. barbui Dumitrică content in these deposits could be related to an increase of the sea level which enabled upwelling circulation along the marginal Silesian Basin that could deliver high-nutrient input to the outer shelf environment. The increase in the content of H. barbui Dumitrică also coincides with the lower input of detrital material and the increased thickness of hemipelagic siltstone and claystone layers. This may additionally suggest deepening of the outer shelf due to global transgression.

After counting all radiolarians taxa found in the samples, divided into deep-dwelling and surface taxa (Figure 10), it can be seen that the greatest diversity and number of them occur in connection with the MCE Ia, MCE Ib and ?MCE II events. Particularly high content of radiolarians from both groups occurred during the event MCE Ib. Taking into account the food preferences of individual groups of radiolarians, it can be assumed that this increased content of deep-water taxa could be related to a high content of nutrients in the deeper part of the water column, which under upwelling conditions, could supply surface waters, where the surface radiolarian group could develop. It is presumed that the development of radiolarians in the Silesian Basin was primarily influenced by periodic changes in the sea level. During the sea level low-stand, the area of shallows was restricted. Thus, recycling of nutrients could be restricted then mostly above the slope favored deep-water assemblages. During sea level rise, the shallow area became expanded and plankton production was beginning to spread to the shelf area being aided by costal upwelling (e.g., [90]). This could be related to the growth of deep-dwelling and shallow-water radiolarian assemblages observed in the sediments, occurring during periods of sea- level rise. This phenomenon may have been caused by an increased supply and recycling of nutrients between the deeper water zone in the Silesian Basin and the surface waters, activated or act more strongly in the periods of rising global sea levels. The question here arises, whether climate warming may significantly affect plankton growth in this process, and whether this factor contributes more to plankton growth than sea-level rise triggering the process of costal upwelling over a large area. The answer to this doubt may be the example from a region of Northwestern Africa, where the heaviest increase of nutrient input recorded as $\delta^{15} \mathrm{~N}$ values was recorded in sediments directly related to a deglaciation period (between 12,000 years $\mathrm{BP}$ and the climatic optimum at $6000 \mathrm{yrs} \mathrm{BP}$ ) but not at the warmest stage [91].

\subsubsection{General Trends in Plankton Distribution in Relation to Sea Level}

The effect of the nutrient content in the water column in relation to sea-level stand and content and proportions of hard-shelled plankton can be seen in the studied sediments 
by comparison of subsection $\mathrm{C}$ and $\mathrm{E}$. The subsection corresponds to record of sea level high-stand, where planktonic foraminifera reach up to $30 \%$. In the subsection $\mathrm{E}$, the content of planktonic foraminifera increases (does not exceed $10 \%$ ), which we interpret as the result of a transgressive cycle. For comparison, the content of radiolarians in the subsection $\mathrm{C}$ is low, while in the subsection E, it increases significantly. This tendency indicates a higher content of nutrients during transgression in the KCe3 cycle (subsection E), which is a likely factor in a greater growth of radiolarians, and at the same time, limits the development of foraminiferal plankton. Such a tendency is a known phenomenon from modern marine environments (e.g., [92]).

The increased frequency of planktonic foraminifera coinciding with the increased content of carbonates on the shelf surrounded the Silesian Basin which coincides with the period of at least the beginning of the long-term transgressive cycle. This period coincided with increased proliferation of calcareous benthic foraminifera in the shelf environment, which lasted during a period of acceleration of transgression and sedimentation of siltstones and claystones in the uppermost part of the MCB and lower part of the BRSF [18].

\section{Conclusions}

Taxonomic composition and trends in abundance of the tests (skeletons) of planktonic foraminiferal and radiolarian assemblages in the redeposited material of the Mikuszowice Chert Beds (Silesian Nappe, Outer Carpathians), as well as changes in the percentage content of biomicrites in the turbidite facies allowed to identify the neritic environment of the peri-Tethyan shelf, in relation to redeposition of calcareous-siliciclastic mud, enriched in sponge spicules induced by sea level third- and first-order fluctuations.

Planktonic foraminifera, in the whole section studied, represent a typical record for the late Albian-middle Cenomanian assemblages known from both pelagic and neritic zones, which are dominated by Hedbergella-like forms, accompanied by biserial P. moremani. Episodic occurrence of taxa reflecting a shallow marine stressful environment, lack of forms living close to low oxygen zone exclude the presence of extreme water conditions on the continental shelf during that time. The radiolarian assemblage is dominated by $H$. barbui Dumitrică which are deep-dwelling forms and prefer nutrient-rich conditions.

Changes in the content of both groups of planktonic biota in material redeposited from shelf facies are here interpreted as fluctuations in their numbers in the neritic zone which were related to the depth of the shelf bottom and supply of nutrients. We recognized here a few trends in planktonic foraminifera which may be correlated with sea level changes of 3rd order including: (a) the record of enhanced content of small, globular planktonic foraminifera during the OAE1d corresponding to the maximum of transgression during the KAl8 cycle, (b) the lowest content of biomicrite microfacies along the Albian-Cenomanian transition and during the early Cenomanian (without its younger part) reflecting the regression cycles of KAl8, (c) the increase in the content of planktonic foraminifera between the layers of allodapic limestone in the upper lower Cenomanian corresponding to the next transgressive cycle (KCe1), (d) the rising abundance of planktonic foraminifera above the MCE Ia and MCE Ib related to transgressive KCe3 cycle.

The radiolarian sea level 3rd order signal is closely related to the distribution of nutrients in the water column. The greatest radiolarian abundance and diversity are related to the MCE Ia, MCE Ib and ?MCE II events. In sediments redeposited from the platform, radiolarians are present during the transgressive cycles, when sea level rise allows the upwelling of fertile waters towards the shelf and support sea-surface assemblies there. This is clearly visible during the transgressive KCe3 cycle which was especially strong due to the first order transgressive cycle at the same time. During regressive and lowstand cycles, radiolarian assemblages contain primarily taxa living in the deeper zones of the water column. 
Supplementary Materials: The following are available online at https: / / www.mdpi.com/article/ 10.3390/min12020152/s1, Table S1: Polycystine radiolaria and planktonic foraminifera from the upper Albian-lower upper Cenomanian in the Barnasiówka-Jasienica section, Silesian Nappe, Outer Carpathians. Note that their abundance is related both to redeposited particles from various microfacies of turbidite sandstone (biomicrite, spiculite) and redeposited/hemipelagic claystone layers (see column: Lithology); R—redeposited species.

Author Contributions: Conceptualization, Z.G. and M.B.; methodology, Z.G.; software, Z.G.; validation, Z.G., M.B., K.B. and P.S.; formal analysis, Z.G.; investigation, Z.G. and M.B.; resources, Z.G. and M.B.; data curation, Z.G.; writing-original draft preparation, Z.G., M.B., K.B. and P.S.; writing-review and editing, Z.G. and M.B.; visualization, Z.G. and K.B.; supervision, Z.G.; project administration, M.B.; funding acquisition, K.B. and M.B. All authors have read and agreed to the published version of the manuscript.

Funding: The study was funded to Krzysztof Bak by the Pedagogical University of Krakow (Grant No. PBN.610-408/PBU/2020) and the Statutory Funds of Department of General Geology and Geotourism, the Faculty of Geology, Geophysics and Environmental Protection, AGH University of Science and Technology to Zbigniew Górny, Marta Bąk and Piotr Strzeboński (Project 16.16.140.315).

Data Availability Statement: Not applicable.

Acknowledgments: We would like to thank two anonymous reviewers and the journal editor for constructive comments and suggestions.

Conflicts of Interest: The authors declare no conflict of interest.

\section{References}

1. Haq, B.U. Cretaceous eustasy revisited. Global Planet. Chang. 2014, 113, 44-58. [CrossRef]

2. Jurkowska, A.; Świerczewska-Gładysz, E.; Bak, M.; Kowalik, S. The role of biogenic silica in the formation of Upper Cretaceous pelagic carbonates and its palaeoecological implications. Cret. Res. 2019, 93, 170-187. [CrossRef]

3. Hemleben, C.; Spindler, M.; Anderson, O.R. Modern Planktonic Foraminifera; Springer: New York, NY, USA, Berlin/Heidelberg, Germany, 1989; p. 363.

4. Gebhardt, H.; Wolfgang, K.; Holbourn, A. Foraminiferal response to sea level change, organic flux and oxygen deficiency in the Cenomanian of the Tarfaya Basin, southern Morocco. Mar. Micropal. 2004, 53, 133-157. [CrossRef]

5. Bak, M.; Bakk, K.; Michalik, M. Decadal to millennial variations in water column parameters in pelagic marine environments of the Western Tethys (Carpathian realm) during Middle-Late Jurassic-evidence from the radiolarian record. Glob. Planet. Chang. 2018, 162, 148-162. [CrossRef]

6. Caron, M.; Homewood, P. Evolution of early planktic foraminifera. Mar. Micropaleontol. 1983, 7, 453-462. [CrossRef]

7. Leckie, R.M. Paleoecology of mid-Cretaceous planktonic foraminifera: A comparison of open ocean and epicontinental sea assemblages. Micropaleontology 1987, 33, 164-176. [CrossRef]

8. Hart, M.B. The evolution and biodiversity of Cretaceous planktonic Foraminiferida. Geobios 1999, 32, 247-255. [CrossRef]

9. Galeotti, S. Planktic and benthic foraminiferal distribution patterns as a response to changes in surface fertility and ocean circulation: A case study from the Late Albian "Amadeus Segment" (Central Italy). J. Micropal. 1998, 17, 87-96. [CrossRef]

10. Coccioni, R.; Luciani, V. Planktonic foraminifera and environmental changes across the Bonarelli Event (OAE2, latest Cenomanian) in its type area: A high resolution study from the Tethyan reference Bottaccione section (Gubbio, central Italy). J. Foram. Res. 2004, 34, 109-129. [CrossRef]

11. Kopaevich, L.F.; Gorbachik, T.N. Shell morphology of Cretaceous planktonic foraminifera as a means for paleoenvironment reconstructions. Paleontol. J. 2017, 51,1-12. [CrossRef]

12. Bak, K. Environmental changes around the Cenomanian-Turonian boundary in a marginal part of the Outer Carpathian Basin expressed by microfacies, microfossils and chemical records in the Skole Nappe (Poland). Ann. Soc. Geol. Polon. 2007, $77,39-67$.

13. Bak, K.; Oszczypko, N. Late Albian and Cenomanian redeposited foraminifera from Late Cretaceous-Paleocene deposits of the Rača subunit (Magura Nappe, Polish Western Carpathians) and their paleogeographical significance. Geol. Carpath. 2000, 51, 371-382.

14. De Wever, P.; Dumitriča, P.; Caulet, J.-P.; Nigrini, C.; Caridroit, M. Radiolarians in the Sedimentary Record; Gordon and Breach Science Publishers: Amsterdam, The Netherland, 2001; p. 533.

15. Bak, M.; Bak, K. Palaeoceanographic regime during the Oxfordian-Kimmeridgian in the western Tethys recorded by radiolarian assemblages in the siliceous sediments of the Pieniny Klippen Belt, Carpathians. Geol. J. 2019, 54, 3362-3375. [CrossRef]

16. Casey, R.E. The Ecology and Distribution of Recent Radiolaria. In Oceanic Micropaleontology; Ramsay, A.T.S., Ed.; Academic Press: London, UK, 1977; Volume 1, pp. 809-841.

17. Matsuoka, A. Living radiolarian feeding mechanisms: New light on past marine ecosystems. Swiss. J. Geosci. 2007, 100, 273-279. [CrossRef] 
18. Bąk, M.; Górny, Z.; Bąk, K. Sponge growth on the Cenomanian carbonate shelves of the Carpathian Basin: A record from spicule-rich turbidites. Bull. Geosci. 2015, 90, 651-666. [CrossRef]

19. Jawor, E. The structure of the deep substratum in the region east of Cracow. Acta Geol. Polon. 1970, 20, 709-770.

20. Moryc, W. Budowa geologiczna podłoża miocenu w rejonie Kraków-Pilzno; Część II. Perm i mezozoik. Nafta-Gaz 2006, 62, 263-282.

21. Bąk, M.; Bakk, K.; Ciurej, A. Mid-Cretaceous spicule-rich turbidites in the Polish Outer Carpathians: Radiolarian and foraminiferal biostratigraphy. Geol. Quart. 2005, 49, 275-290.

22. Bak, M.; Bakk, K.; Ciurej, A. Palaeoenvironmental signal from the microfossils record in the Mikuszowice Cherts of the Silesian Nappe, Polish Outer Carpathians. In Integrating Microfossils Record from the Oceans and Epicontinental Seas; Bak,, M., Kaminski, M.A., Waśkowska, A., Eds.; Grzybowski Foundation Special Publication: London, UK, 2011; Volume 17, pp. 15-25.

23. Bak, M. Cretaceous radiolaria from Niedzica succession of the Pieniny Klippen Belt in Polish Carpathians. Acta Palaeontol. Polon. 1996, 41, 91-110.

24. Bak, M. Radiolarian biostratigraphy of the upper Cenomanian-lower Turonian deposits in the Subsilesian Nappe (Outer Western Carpathians). Geol. Carpath. 2004, 55, 239-250.

25. Bak, K.; Bak, M. Foraminiferal and radiolarian biostratigraphy of the youngest (Late Albian through Late Cenomanian) sediments of the Tatra massif, Central Western Carpathians. Acta Geol. Polon. 2013, 63, 223-237. [CrossRef]

26. Bakk, K.; Bąk, M.; Dulemba, P.; Okoński, S. Late Cenomanian environmental conditions at the submerged Tatric Ridge, Central Western Carpathians during the period preceding Oceanic Anoxic Event 2-A palaeontological and isotopic approach. Cret. Res. 2016, 63, 95-112. [CrossRef]

27. Żytko, K. Correlation of the main structural units of Western and Eastern Carpathians. Prace Państw. Inst. Geol. Warszawa 1999, 168, 135-164. (In Polish)

28. Burtan, J. Detailed Geological Map of Poland in Scale 1:50,000 (without Quaternary Sediments); The Carpathian and Fore-Carpathian Area: Myślenice Sheet; Wydawnictwa Geologiczne: Warsaw, Poland, 1964.

29. Koszarski, L.; Ślączka, A. Outer (flysch) Carpathians. Lower Cretaceous. In Geology of Poland, Volume 1 Stratigraphy, Part 2 Mesozoic; Sokołowski, S., Cieśliński, S., Czermiński, J., Pajchlowa, M., Eds.; Geological Institute: Warsaw, Poland, 1973; pp. $492-495$.

30. Bak, M. Radiolaria from the Upper Cenomanian-Lower Turonian deposits of the Silesian Unit (Polish Flysch Carpathians). Geol. Carpath. 2000, 51, 309-324.

31. Bakk, K.; Bąk, M.; Paul, Z. Barnasiówka Radiolarian Shale Formation-A new lithostratigraphic unit in the Upper Cenomanianlowermost Turonian of the Polish Outer Carpathians (Silesian Series). Ann. Soc. Geol. Polon. 2001, 71, 75-103.

32. Bąk, M.; Bąk, K.; Górny, Z. Timing of mass redeposition of sponge spicules from the peri-Tethyan shelf into the deep Carpathian basin and their relation to mid-Cretaceous global sea level changes. Bull. Geol. Soc. Am. 2021; in press.

33. Golonka, J.; Gahagan, L.; Krobicki, M.; Marko, F.; Oszczypko, N.; Slączka, A. Plate Tectonic Evolution and Paleogeography of the Circum-Carpathian Region. In The Carpathians and Their Foreland: Geology and Hydrocarbon Resources; Golonka, J., Picha, F., Eds.; American Association of Petroleum Geologists Memoir: Tulsa, OK, USA, 2006; Volume 84, pp. 11-46.

34. Oszczypko, N. Late Jurassic-Miocene evolution of the Outer Carpathian fold-and thrust belt and its foredeep basin (Western Carpathians, Poland). Geol. Quart. 2006, 50, 169-194.

35. Golonka, J.; Oszczypko, N.; Ślączka, A. Late Carboniferous-Neogene geodynamic evolution and palaeogeography of the circum-Carpathian region and adjacent areas. Ann. Soc. Geol. Polon. 2000, 70, 107-136.

36. Książkiewicz, M. Stratigraphical-Facial Problems: Cretaceous and Older Palaeogene in Polish Outer Carpathians. In Geological Atlas of Poland; Geological Institute: Warsaw, Poland, 1962.

37. Nemčok, M.; Nemčok, J.; Wojtaszek, M.; Ludhova, L.; Oszczypko, N.; Sercombe, W.J.; Cieszkowski, M.; Paul, Z.; Coward, M.P.; Ślaczzka, A. Reconstruction of Cretaceous rifts incorporated in the Outer West Carpathian wedge by balancing. Mar. Petrol. Geol. 2001, 18, 39-64. [CrossRef]

38. Unrug, R. The Silesian cordillera as the source of clastic material of the Flysch sandstones of the Beskid Ślaski and Beskid Wysoki ranges, Polish West Carpathians. Ann. Soc. Géol. Pol. 1968, 38, 81-164.

39. Kowal-Kasprzyk, J.; Waśkowska, A.; Golonka, J.; Krobicki, M.; Skupien, P.; Słomka, T. The Late Jurassic-Palaeogene Carbonate Platforms in the Outer Western Carpathian Tethys-A Regional Overview. Minerals 2021, 11, 747. [CrossRef]

40. Reid, R.E.H. A Monograph of the Upper Cretaceous Hexactinellida of Great Britain and Northern Ireland; Palaeontographical Society: London, UK, 1958; p. 26.

41. Termier, G.; Termier, H. Spongiaires du Crétacé Moyen. Cret. Res. 1980, 2, 427-433. [CrossRef]

42. Olszewska-Nejbert, D.; Świerczewska-Gładysz, E. Cenomanian (Late Cretaceous) siliceous sponges from Nezvys'ko and Rakovets' (Pokuttian Podillia, western Ukraine). Cret. Res. 2013, 43, 116-144. [CrossRef]

43. Bąk, K.; Bąk, M.; Górny, Z.; Wolska, A. Environmental conditions in a Carpathian deep sea basin during the period preceding Oceanic Anoxic Event 2-A case study from the Skole Nappe. Geol. Carpath. 2014, 65, 433-450. [CrossRef]

44. Sujkowski, Z. Sur certains spongiolithes de la Tatra et des Karpates. Spraw. Państw. Inst. Geol. 1933, 7, 712-733. (In Polish)

45. Książkiewicz, M. Geology of the Northern Carpathians. Geol. Rund. 1956, 45, 396-411. [CrossRef]

46. Alexandrowicz, S.W. Gaize-type sediments in the Carpathian flysch. Neues J. Geol. Paläont. 1973, 1, 1-17.

47. Bak, M. Cretaceous radiolarian zonation in the Polish part of the Pieniny Klippen Belt (Western Carpathians). Geol. Carpath. 1999, $50,21-31$. 
48. Bak, K. Environmental changes during the Cenomanian-Turonian boundary event in the Outer Carpathian basins: A synthesis of data from various tectonic-facies units. Ann. Soc. Geol. Polon. 2007, 77, 171-191.

49. Bak, M.; Bak, K. Termination of Organic-Rich Accumulation of the Oceanic Anoxic Event 2 in the Deep-Water Carpathian Basins Based on Carbon Stable Isotope Data. Minerals 2021, 11, 420. [CrossRef]

50. Bak, M. Tethyan radiolarians at the Cenomanian-Turonian anoxic event from the Apennines (Umbria-Marche) and the Outer Carpathians: Palaeoecological and palaeoenvironmental implications. Studia Geol. Polon. 2011, 134, 7-279.

51. Olszewska, B. Foraminiferal biostratigraphy of the Polish Outer Carpathians: A record of basin geohistory. Ann. Soc. Geol. Polon. 1997, 67, 325-337.

52. Bąk, K. Biostratigraphy of deep-water agglutinated Foraminifera in Scaglia Rossa-type deposits of the Pieniny Klippen Belt, Carpathians, Poland. In Proceedings of the Fifth International Workshop on Agglutinated Foraminifera, Plymouth, UK, 12-19 September 1997; Hart, M.B., Kaminski, M.A., Smart, C., Eds.; Grzybowski Foundation Special Publication: London, UK, 2000; Volume 7, pp. 15-40.

53. Baccelle, L.; Bosellini, A. Diagrammi per la stima visiva della composizione percentuale nelle rocce sedimentarie. Ann. Univ. Ferrara (N. Serie) Sez. 9 Sci. Geol. Paleont. 1965, 1, 117-153.

54. Bąk, M.; Górny, Z.; Bąk, K.; Wolska, A.; Stożek, B. Successive stages of calcitization and silicification of Cenomanian spicule-bearing turbidites based on microfacies analysis, Polish Outer Carpathians. Ann. Soc. Geol. Polon. 2015, 85, 187-203. [CrossRef]

55. Bąk, M.; Bąk, K.; Górny, Z.; Stożek, B. Evidence of bacteriogenic iron and manganese oxyhydroxides in Albian-Cenomanian marine sediments of the Carpathian realm (Poland). Ann. Soc. Geol. Polon. 2015, 85, 371-385. [CrossRef]

56. Kostka, A.; Widz, D. Nowa metoda wydobywania mikroskamieniałości z twardych skałwęglanowych. Przegl. Geol. Warsaw 1986, 9, 461. (In Polish)

57. Sanfilippo, A.; Riedel, W.R. Cretaceous Radiolaria. Plankton Stratigraphy. In Plankton Stratigraphy; Bolli, H.M., Saunders, J.B., Perch-Nielsen, K., Eds.; Cambridge University Press: Cambridge, UK, 1985; pp. 573-630.

58. Abelmann, A.; Gowing, M.M. Horizontal and vertical distribution pattern of living radiolarians along a transect from the Southern Ocean to the South Atlantic Subtropical region. Deep-Sea Res. I 1996, 43, 361-382. [CrossRef]

59. Elderbak, K.; Leckie, R.M.; Tibert, N.E. Paleoenvironmental and paleoceanographic changes across the Cenomanian-Turonian Boundary Event (Oceanic Anoxic Event 2) as indicated by foraminiferal assemblages from the eastern margin of the Cretaceous Western Interior Sea. Palaeogeogr. Palaeoecol. Palaeoclim. 2014, 413, 29-48. [CrossRef]

60. Bijma, J.; Faber, W.W.; Hemleben, C. Temperature and salinity limits for growth and survival of some planktonic foraminifers in laboratory cultures. J. Foram. Res. 1990, 20, 95-116. [CrossRef]

61. Rickaby, R.E.M.; Elderfield, H. Planktonic foraminiferal Cd/Ca: Paleonutrients or paleotemperature. Paleoceanography 1999, 14, 293-303. [CrossRef]

62. Schiebel, R.; Waniek, J.; Bork, M.; Hemleben, C. Planktic foraminiferal production stimulated by chlorophyll redistribution and entrainment of nutrients. Deep-Sea Res. I 2001, 48, 721-740. [CrossRef]

63. Sousa, S.H.M.; Godoi, S.S.; Amaral, P.G.C.; Vicente, T.M.; Martins, M.V.A.; Sorano, M.R.G.S.; Gaeta, S.A.; Passos, R.F.; Mahiques, M.M. Distribution of living planktonic foraminifera in relation to oceanic processes on the southeastern continental Brazilian margin $\left(23^{\circ} \mathrm{S}-25^{\circ} \mathrm{S}\right.$ and $\left.40^{\circ} \mathrm{W}-44^{\circ} \mathrm{W}\right)$. Contin. Shelf Res. 2014, 89, 76-87. [CrossRef]

64. Shackleton, N. Depth of pelagic foraminifera and isotopic changes in Pleistocene oceans. Nature 1968, 218, 79-80. [CrossRef]

65. Mortyn, P.G.; Charles, C.D. Planktonic foraminiferal depth habitat and $\delta^{18} \mathrm{O}$ calibrations: Plankton tow results from the Atlantic sector of the Southern Ocean. Paleoceanography 2003, 18, 1037. [CrossRef]

66. Greco, M.; Jonkers, L.; Kretschmer, K.; Bijma, J.; Kucera, M. Depth habitat of the planktonic foraminifera Neogloboquadrina pachyderma in the northern high latitudes explained by sea-ice and chlorophyll concentrations. Biogeoscience 2019, 16, 3425-3437. [CrossRef]

67. Hart, M.B. A water depth model for the evolution of the planktonic Foraminiferida. Nature 1990, 286, 252-254. [CrossRef]

68. Casey, R.; Gust, L.; Leavesley, A.; Williams, D.; Reynolds, R.; Duis, T.; Spaw, M. Ecological niches of radiolarians, planktonic foraminiferans and pteropods inferred from studies on living forms in the Gulf of Mexico and adjacent waters. Trans. Gulf Coast Assoc. Geolog. Soc. 1979, 24, 216-223.

69. Premoli Silva, I.; Sliter, W.V. Cretaceous Paleoceanography: Evidence from Planktonic Foraminiferal Evolution. In Evolution of the Cretaceous Ocean-Climate System; Barrera, E., Johnson, C.C., Smart, C., Eds.; Geological Society of America: Boulder, CO, USA , 1999; Volume 332, pp. 301-328.

70. Gasiński, M.A. Tethyan-Boreal connection: Influence on the evolution of mid-Cretaceous planktonic foraminiferids. Cret. Res. 1997, 18, 505-514. [CrossRef]

71. Ando, A.; Huber, B.T.; MacLeod, K.G. Depth-habitat reorganization of planktonic foraminifera across the Albian/Cenomanian boundary. Paleobiology 2010, 36, 357-373. [CrossRef]

72. Wilson, P.A.; Norris, R.D. Warm tropical ocean surface and global anoxia during the mid-Cretaceous period. Nature 2001, 412, 425-429. [CrossRef] [PubMed]

73. Leckie, R.M.; Bralower, T.J.; Cashman, J. Oceanic anoxic events and plankton evolution: Biotic response to tectonic forcing during the mid-Cretaceous. Paleoceanography 2002, 17, 1041. [CrossRef]

74. Machalski, M.; Kennedy, W.J. Oyster-bioimmured ammonites from the Upper Albian of Annopol, Poland: Stratigraphie and palaeobiogeographic implications. Acta Geol. Polon. 2013, 63, 545-554. [CrossRef] 
75. Dubicka, Z.; Machalski, M. Foraminiferal record in a condensed marine succession: A case study from the Albian and Cenomanian (mid-Cretaceous) of Annopol, Poland. Geol. Mag. 2017, 154, 399-418. [CrossRef]

76. Nederbragt, A.J.; Erlich, R.N.; Fouke, B.W.; Ganssen, G.M. Palaeoecology of the biserial planktonic foraminifer Heterohelix moremani (Cushman) in the late Albian to middle Turonian Circum-North Atlantic. Palaeogeogr. Palaeoclim. Palaeoecol. 2006, 235 , 66-92. [CrossRef]

77. Keller, G.; Pardo, L. Disaster opportunists Guembelitrinidae: Index for environmental catastrophes. Mar. Micropal. 2004, 53, 83-116. [CrossRef]

78. Mukhopadhyay, S.K. Guembelitria (foraminifera) in the Upper Cretaceous-Lower Paleocene succession of the Langpar Formation, India and its paleoenvironmental implication. J. Geol. Soc. India 2012, 79, 627-651. [CrossRef]

79. Coccioni, R.; Luciani, V.; Marsili, A. Cretaceous oceanic anoxic events and radially elongated chambered planktonic foraminifera: Paleoecological and paleoceanographic implications. Palaeogeogr. Palaeoclim. Palaeoecol. 2006, 235, 66-92. [CrossRef]

80. Petrizzo, M.R.; Huber, B.T.; Wilson, P.A.; MacLeod, K.G. Late Albian paleoceanography of the western subtropical north Atlantic. Paleoceanography 2008, 23, 1-17. [CrossRef]

81. Bottini, C.; Erba, E. Mid-Cretaceous paleoenvironmental changes in the western Tethys. Clim. Past 2018, 14, 1147-1163. [CrossRef]

82. Gibson, T.G. Planktonic benthonic foraminiferal ratios: Modern patterns and Tertiary applicability. Mar. Micropaleontol. 1989, 15, 29-52. [CrossRef]

83. Van der Zwaan, G.J.; Jorissen, F.J.; de Stigter, H.C. The depth dependency of planktonic/benthic foraminiferal ratios: Constraints and applications. Mar. Geol. 1990, 95, 1-16. [CrossRef]

84. Coccioni, R.; Galeotti, S. The mid-Cenomanian Event: Prelude to OAE 2. Palaeogeogr. Palaeoclim. Palaeoecol. 2003, 190, 427-440. [CrossRef]

85. Bakk, M. Mid Cretaceous Radiolaria from the Pieniny Klippen Belt, Carpathians, Poland. Cret. Res. 1995, 16, 1-23. [CrossRef]

86. Ciurej, A.; Bąk, M.; Szczerba, M. Biostratinomy and Diagenetic Impact on Exceptional Preservation of Coccospheres from Lower Oligocene Coccolith Limestones. Minerals 2020, 10, 616. [CrossRef]

87. Boltovskoy, D.; Jankilevich, S.S. Radiolarian distribution in east Equatorial Pacific plankton. Oceanol. Acta 1985, 8, 101-123.

88. Takahashi, K. Siliceous microplankton fluxes in the eastern subarctic Pacific, 1982-1986. J. Oceanogr. 1997, 53, 455-466.

89. Bak, M. Abdomen wall structure of Holocryptocanium barbui (Radiolaria). J. Micropal. 1996, 15, 131-134. [CrossRef]

90. Boyle, E.A. Vertical oceanic nutrient fractionation and glacial/interglacial $\mathrm{CO}_{2}$ cycles. Nature 1988, 331, 55-56. [CrossRef]

91. Bertrand, P.; Pedersen, T.F.P.; Martinez, P.; Calvert, S.; Shimmield, G. Sea level impact on nutrient cycling in coastal upwelling areas during deglaciation: Evidence from nitrogen isotopes. Glob. Biogeochem. Cycles 2000, 14, 341-355. [CrossRef]

92. Leckie, R.M.; Olson, H. Foraminifera as proxies of sea-level change on siliciclastic margins. In Micropaleontologic Proxies of Sea-Level Change and Stratigraphic Discontinuities; Olson, H.C., Leckie, R.M., Eds.; Special Publication, SEPM (Society of Sedimentary Geology): Tulsa, OK, USA, 2003; pp. 5-19. 